\title{
Istotny pogląd Rzecznika Finansowego jako instrument ochrony klientów podmiotów rynku finansowego
}

\section{Wprowadzenie}

Celem artykułu jest zaprezentowanie kompetencji Rzecznika Finansowego do przedstawienia sądowi istotnego dla sprawy poglądu (istotnego poglądu), a także zasygnalizowanie wątpliwości i problemów, jakie w praktyce mogą się wiązać ze stosowaniem tego instrumentu. Na rynku, a zwłaszcza na rynku finansowym niejednokrotnie oferowane są złożone usługi i produkty, mające skomplikowany lub ryzykowny charakter. Warto przy tym dodać, że często "nowe" produkty w istocie stanowią zmodyfikowane lub zapomniane produkty już wcześniej funkcjonujące na rynku. Mimo postulatu, aby umowy - zwłaszcza jeżeli zawierane są z konsumentami - spełniały wymóg formalnej ${ }^{1} \mathrm{i}$ materialnej transparentności ${ }^{2}$, usługi i produkty finansowe - a zwłaszcza różne rodzaje ryzyka lub ich skutki - nie zawsze są dla klientów w pełni zrozumiałe.

${ }^{1}$ Wymóg wyrażania warunków umowy prostym i zrozumiałym językiem wynika z motywu 20 art. 4 ust. 2 i art. 5 Dyrektywy Rady 93/13/EWG z dnia 5 IV 1993 r. w sprawie nieuczciwych warunków w umowach konsumenckich (OJ L 95 z 21 IV 1993, s. 29-34).

${ }^{2}$ Wyrok Trybunału Sprawiedliwości Unii Europejskiej (TSUE) z 21 XII 2016 r. w sprawach połączonych C-154/15, C-307/15 i C-308/15 (ECLI:EU:C:2016:980), pkt 21, 50 i 51; wyrok TSUE z 21 III 2013 r. w sprawie C-92/11 (ECLI:EU:C:2013:180), pkt 44; wyrok TSUE z 30 IV 2014 r. w sprawie C-26/13 (ECLI:EU:C:2014:282), pkt 74; wyrok TSUE z 23 IV 2015 r. w sprawie C-96/14 (ECLI:EU:C:2015:262), pkt 47. W sprawie zasady materialnej przejrzystości umowy zob. M. Romanowski, Zasada przejrzystości materialnej umowy konsumenckiej, w: Życie umowy konsumenckiej po uznaniu jej postanowienia za nieuczciwe na tle orzecznictwa TSUE, Rozdział VI, pod red. M. Romanowskiego, Warszawa 2017. 
W konsekwencji coraz częściej, np. w przypadku ewentualnych nieprawidłowości związanych ze sposobem ich oferowania i sprzedaży (zarzut missellingu ${ }^{3}$ ), czy też w przypadku zastrzeżeń dotyczących treści umó $^{4}$ - które z klientami detalicznymi generalnie zawierane są na zasadzie adhezji - klienci decydują się dochodzić swoich praw na drodze sądowej. Nierzadko też to klienci bywają pozywani przez podmioty rynku finansowego. Słusznie postuluje się, aby poddanie sprawy pod rozstrzygnięcie sądu nastąpiło dopiero wówczas, gdy pozostałe możliwości rozwiązania sporu - w szczególności te o charakterze polubownym - nie przyniosą pozytywnych efektów. W postulat ten wpisuje się również instytucja Rzecznika Finansowego, posiadającego kompetencję do przeprowadzania pozasądowego postępowania w sprawie rozwiązywania sporów między klientem a podmiotem rynku finansowego ${ }^{5}$. Niemniej Rzecznik Finansowy wyposażony został również w instrument, który ma na celu wsparcie klientów będących - bądź to jako strona powodowa, bądź to jako strona pozwana - w sporach z podmiotami rynku finansowego na etapie postępowania sądowego. Jest nim uprawnienie do przedstawienia sądowi istotnego dla sprawy poglądu. Jego przedłożenie ma umożliwić transfer wiedzy i doświadczeń Rzecznika Finansowego - jako organu wyspecjalizowanego w sprawach dotyczących szeroko rozumianego rynku finansowego - do sądu.

${ }^{3} \mathrm{~W}$ polskim prawie brak jest definicji legalnej pojęcia missellingu. W praktyce przyjmuje się, że chodzi o sytuacje, w których klient wprowadzany jest w błąd co do rzeczywistych właściwości, ryzyka lub skutków ekonomicznych związanych z daną usługą lub produktem, bądź o przypadki oferowania produktów lub usług nieadekwatnych do potrzeb lub cech klientów. Warto dodać, że zgodnie z art. 24 ust. 2 pkt 4 Ustawy z dnia 16 II 2007 r. o ochronie konkurencji i konsumentów (Dz.U. Nr 50, poz. 331 ze zm., dalej "ustawa o ochronie konkurencji i konsumentów”) „Przez praktykę naruszającą zbiorowe interesy konsumentów rozumie się godzące w nie sprzeczne z prawem lub dobrymi obyczajami zachowanie przedsiębiorcy, w szczególności proponowanie konsumentom nabycia usług finansowych, które nie odpowiadają potrzebom tych konsumentów ustalonym z uwzględnieniem dostępnych przedsiębiorcy informacji w zakresie cech tych konsumentów lub proponowanie nabycia tych usług w sposób nieadekwatny do ich charakteru". Przepis ten wprowadzony został Ustawą z dnia 5 VIII 2015 r. o zmianie ustawy o ochronie konkurencji i konsumentów oraz niektórych innych ustaw (Dz.U. poz. 1634), która weszła w życie 17 IV 2016 r.

${ }^{4}$ Najczęściej klienci wskazują na nietransparentność poszczególnych postanowień umów (wzorców umów) i wątpliwości interpretacyjne z tym związane bądź też podnoszą, że postanowienia mogą mieć nieuczciwy charakter.

${ }^{5}$ Rozdział 4 (artykuły 35-43) Ustawy z dnia 5 VIII 2015 r. o rozpatrywaniu reklamacji przez podmioty rynku finansowego i o Rzeczniku Finansowym (Dz.U. poz. 1348 ze zm.), dalej „ustawa o Rzeczniku”. 
Już na wstępie warto zasygnalizować, że z jednej strony instytucja istotnego poglądu jako taka nie stanowi novum w polskim systemie prawnym, gdyż od momentu wejścia w życie Kodeksu postępowania cywilnego ${ }^{6}$ przewidziana jest $w$ art. 63 tego aktu. Zgodnie $z$ tym przepisem wymienione w k.p.c. organizacje pozarządowe, jeżeli nie uczestniczą w sprawie, mogą przedstawiać sądowi istotny dla sprawy pogląd wyrażony w uchwale lub w oświadczeniu ich należycie umocowanych organów. Chodzi o organizacje pozarządowe, których zadania statutowe nie polegają na prowadzeniu działalności gospodarczej ${ }^{7}$, lecz należy do nich ochrona praw obywateli w zakresie, który obejmuje sprawy wymienione $w$ art. $61 \S 1$ lub $\S 3$ k.p.c. $Z$ drugiej strony, stosunkowo niedawne nadanie omawianego uprawnienia Rzecznikowi Finansowemu ${ }^{8}$, a także Prezesowi Urzędu Ochrony Konkurencji i Konsumentów (Prezesowi UOKiK) ${ }^{9}$ powoduje, że w praktyce może ono nabrać nowego znaczenia i pozytywnie wpływać na orzecznictwo, a być może nawet je współkształtować w sprawach dotyczących klientów, w tym konsumentów na szeroko rozumianym rynku finansowym.

W niniejszym opracowaniu w pierwszej kolejności omówione zostaną podstawowe zagadnienia związane $\mathrm{z}$ uprawnieniem Rzecznika Finansowego do wydania istotnego poglądu w sprawie. Ustalenia wymaga przede wszystkim, w jakich okolicznościach i w jakich sprawach Rzecznik Finansowy może wydać istotny pogląd, a kiedy taką możliwość należy uznać za niedopuszczalną lub niepożądaną. Konieczne będzie przy tym odwołanie się do ustawowych zadań i celów, jakie Rzecznik Finansowy powinien realizować. Następnie dokonana zostanie analiza charakteru prawnego istotnego poglądu, zmierzająca do oceny, jaką funkcję i znaczenie należy mu przypisać w postępowaniu cywilnym. Zostanie przy tym omówione, jaką treść i zakres powinien mieć istotny pogląd. Nie sposób również nie przeprowadzić analizy prawnoporównawczej odnoszącej się do zbliżonej kompetencji Prezesa UOKiK w tym zakresie. Mimo podobieństw

${ }^{6}$ Ustawa z dnia 17 XI 1964 r. - Kodeks postępowania cywilnego (Dz.U. Nr 43, poz. 296 ze zm.), dalej „k.p.c.”, obowiązująca od 1 I 1965 r.

${ }^{7}$ Artykuł 8 k.p.c.

${ }^{8}$ Artykuł 28 ustawy o Rzeczniku obowiązującej od 11 X 2015 r.

${ }_{9}^{9}$ Artykuł 31d ustawy o ochronie konkurencji i konsumentów wprowadzony został Ustawą z dnia 5 VIII 2015 r. o zmianie ustawy o ochronie konkurencji i konsumentów oraz niektórych innych ustaw (Dz.U. poz. 1634), obowiązującą od 17 IV 2016 r. 
występują bowiem pewne odrębności. Wreszcie zasygnalizowana zostanie problematyka związana z tym, czy treść istotnego poglądu, bądź też poszczególne informacje w nim zawarte, mogą stanowić informację publiczną w rozumieniu ustawy o dostępie do informacji publicznej ${ }^{10}$. Warto dodać, że zaprezentowana analiza w pewnej części odnosić się będzie do instytucji istotnego poglądu w ogólności, a więc niezależnie od tego, czy z omawianego uprawnienia miałby korzystać Rzecznik Finansowy, Prezes UOKiK czy organizacje pozarządowe. W szczególności chodzi o paragraf 6, w którym omawiany jest charakter prawny i rola istotnego poglądu $\mathrm{w}$ postępowaniu sądowym. W pozostałym zakresie uwagi odnosić się będą stricte do kompetencji Rzecznika Finansowego.

\section{Istotny dla sprawy pogląd $w$ świetle art. 63 k.p.c.}

Na wstępie należy wskazać, że ustawa o Rzeczniku prima facie nie przewiduje odrębnej regulacji odnoszącej się do istotnego poglądu, lecz nakazuje odpowiednie stosowanie do Rzecznika Finansowego art. 63 k.p.c. Zgodnie z tym przepisem „Organizacje pozarządowe wymienione $\mathrm{w}$ artykułach poprzedzających, które nie uczestniczą w sprawie, mogą przedstawiać sądowi istotny dla sprawy pogląd wyrażony w uchwale lub w oświadczeniu ich należycie umocowanych organów". Mimo że Rzecznik Finansowy funkcjonuje dopiero od 11 października 2015 r., uprawnienie to $\mathrm{w}$ odniesieniu do pewnej części rynku finansowego, a mianowicie rynku ubezpieczeniowego i emerytalnego, nie stanowi nowości. Należy bowiem pamiętać, że Rzecznik Finansowy jest swego rodzaju następcą prawnym Rzecznika Ubezpieczonych (art. 54-62 ustawy o Rzeczniku) ${ }^{11}$, który to organ funkcjonował od 1995 r. ${ }^{12}$ Pierwotnie

${ }^{10}$ Ustawa z dnia 6 IX 2001 r. o dostępie do informacji publicznej (Dz.U. Nr 112, poz. 1198 ze zm.), dalej „u.o.d.i.p.”.

${ }^{11} \mathrm{~W}$ uzasadnieniu do poselskiego projektu ustawy o rozpatrywaniu reklamacji przez podmioty rynku finansowego i o Rzeczniku Finansowym (druk nr 3430/VII kadencja), s. 16, http://www.sejm.gov.pl/sejm7.nsf/druk.xsp?nr=3430 (dostęp: 21 II 2018), wskazano, że "Rzecznik Finansowy przejmie dotychczasowe kompetencje Rzecznika Ubezpieczonych, przy czym jego obszar kompetencyjny będzie obejmował wszystkie sektory rynku finansowego".

${ }^{12}$ Rozdział 10b (art. 90b-90d) Ustawy z dnia 28 VII 1990 r. o działalności ubezpieczeniowej (Dz.U. Nr 59, poz. 344 ze zm.), dalej „ustawa o działalności ubezpieczeniowej”, który wprowadzony został na mocy art. 1 pkt 80 Ustawy z dnia 8 VI 1995 r. o zmianie ustawy o działalności ubezpieczeniowej, o zmianie rozporządzenia Prezydenta 
Rzecznik Ubezpieczonych nie miał kompetencji do wydawania istotnych poglądów, co uległo zmianie wraz z wejściem w życie ustawy o przeciwdziałaniu nieuczciwym praktykom rynkowym ${ }^{13}$. Na jej mocy do ustawy o nadzorze ubezpieczeniowym i emerytalnym wprowadzony został art. 26 ust. $7^{14}$, zgodnie z którym do Rzecznika Ubezpieczonych stosowało się odpowiednio przepis art. 63 k.p.c.

Rzecznik Finansowy przejął zatem kompetencję, która od wielu lat przysługiwała Rzecznikowi Ubezpieczonych. Należy jednak pamiętać, że "siła rażenia" tego instrumentu zasadniczo zawężona była do spraw dotyczących osób ubezpieczających, ubezpieczonych, uposażonych lub uprawnionych z umów ubezpieczenia, członków funduszy emerytalnych i uczestników pracowniczych programów emerytalnych $^{15}$ - innymi słowy, do spraw mieszczących się $\mathrm{w}$ granicach nadzoru ubezpieczeniowego i emerytalnego ${ }^{16}$. Obecnie uprawnienie to jest znacznie szersze i obejmuje również takie rynki, jak np. rynek bankowy, pożyczkowy, kapitałowy czy rynek usług płatniczych. Między innymi w tym kontekście aktualizuje się konieczność odpowiedniego stosowania art. 63 k.p.c., co oznacza, że to przepisy ustawy o Rzeczniku wyznaczać będą zakres podmiotowy i przedmiotowy spraw (sporów), $\mathrm{w}$ jakich przedstawienie istotnego poglądu przez Rzecznika Finansowego będzie dopuszczalne. Konieczność odpowiedniego stosowania art. 63 k.p.c. objawia się także na innych płaszczyznach, które zostaną kolejno omówione.

Rzeczypospolitej - Kodeks handlowy oraz o zmianie ustawy o podatku dochodowym od osób prawnych (Dz.U. Nr 96, poz. 478) i obowiązywał od 20 X 1995 r. do 1 I 2004 r. Tego dnia w życie weszła Ustawa z dnia 22 V 2003 r. o nadzorze ubezpieczeniowym i emerytalnym (Dz.U. Nr 124, poz. 1153 ze zm.), dalej „ustawa o nadzorze ubezpieczeniowym i emerytalnym". Zasady działania Rzecznika Ubezpieczonych uregulowane zostały w przepisach rozdziału 3 (art. 19-30) ustawy o nadzorze ubezpieczeniowym i emerytalnym.

${ }^{13}$ Ustawa z dnia 23 VIII 2007 r. o przeciwdziałaniu nieuczciwym praktykom rynkowym (Dz.U. Nr 171, poz. 1206 ze zm.), dalej „u.p.n.p.r.” obowiązująca od 21 XII 2007 r.

${ }^{14}$ Artykuł 19 pkt 2 u.p.n.p.r.

${ }^{15}$ Artykuł 5 ust. 1 ustawy o nadzorze ubezpieczeniowym i emerytalnym.

${ }^{16}$ Artykuł 2 ustawy o nadzorze ubezpieczeniowym i emerytalnym wskazywał rodzaje działalności i podmioty podlegające nadzorowi. Zgodnie z art. 2 ust. 2 tego aktu nadzorowi podlegały w szczególności zakłady ubezpieczeń, pośrednicy ubezpieczeniowi, fundusze emerytalne i towarzystwa emerytalne. Zgodnie z jego art. 3 celem nadzoru była ochrona interesów osób ubezpieczających, ubezpieczonych, uposażonych lub uprawnionych z umów ubezpieczenia, członków funduszy emerytalnych oraz uczestników pracowniczych programów emerytalnych. 


\section{Ochrona klientów podmiotów rynku finansowego}

W celu ustalenia, w jakich sporach Rzecznik Finansowy może wydać istotny pogląd dla sprawy, należy się odwołać do jego ustawowych zadan ${ }^{17}$. Wynikają one w pierwszej kolejności z art. 17 ustawy o Rzeczniku, choć w celu ich dookreślenia konieczne jest również odwołanie się do definicji klienta i podmiotu rynku finansowego, zawartych odpowiednio $\mathrm{w}$ art. 2 pkt $1 \mathrm{i}$ art. 2 pkt 3 tego aktu. Zgodnie $\mathrm{z}$ art. 17 in principio ustawy o Rzeczniku do zadań Rzecznika Finansowego należy podejmowanie działań w zakresie ochrony klientów podmiotów rynku finansowego, których interesy reprezentuje ${ }^{18}$. Podmioty rynku finansowego zostały enumeratywnie wskazane w art. 2 pkt 3 ustawy o Rzeczniku poprzez odesłanie do odpowiednich przepisów ustaw szczególnych, które niekiedy odsyłają do kolejnych ustaw lub aktów prawa unijnego ${ }^{19}$. Artykuł 2 pkt 3 ustawy o Rzeczniku należy jednak interpretować w powiązaniu z pkt 1 tego artykułu, który zawiera z kolei definicję klienta podmiotu rynku finansowego. $Z$ analizy tych przepisów wynika, że klientem podmiotu rynku finansowego może być każda osoba fizyczna, i to niezależnie od tego, czy ma przymiot konsumenta czy przedsiębiorcy. Klientem może być zatem również osoba fizyczna, która nie jest ani konsumentem,

${ }^{17}$ Natomiast w celu ustalenia, czy organizacje pozarządowe będą uprawnione do przedstawienia sądowi istotnego poglądu dla sprawy, konieczne jest odwołanie się do ich zadań statutowych (art. 8, art. 61 § 1 i 3 w zw. z art. 63 k.p.c.).

${ }^{18} \mathrm{Z}$ kolei zgodnie $\mathrm{z}$ art. 1 ustawy o Rzeczniku „Ustawa określa zasady rozpatrywania reklamacji przez podmioty rynku finansowego, składanych przez klientów tych podmiotów oraz zasady działania Rzecznika Finansowego".

${ }^{19}$ Przykładowo, zgodnie z art. 2 pkt 3 lit. b podmiotem rynku finansowego jest m.in. „instytucja finansowa w rozumieniu ustawy z dnia 29 sierpnia 1997 r. - Prawo bankowe (Dz.U. 2017 r., poz. 1876)". Natomiast zgodnie z art. 4 ust. 1 pkt 7 Ustawy z dnia 29 VIII 1997 r. - Prawo bankowe (Dz.U. Nr 140, poz. 939) instytucja finansowa oznacza: „instytucję finansowa, o której mowa w art. 4 ust. 1 pkt 26 rozporządzenia nr 575/2013". Zgodnie z art. 4 ust. 1 pkt 26 Rozporządzenia Parlamentu Europejskiego i Rady (UE) nr 575/2013 z dnia 26 VI 2013 r. w sprawie wymogów ostrożnościowych dla instytucji kredytowych i form inwestycyjnych, zmieniające rozporządzenie (UE) nr 648/2012 z dnia 26 VI 2013 r. (Dz.Urz. UE L 176 z 27 VI 2013 r., s. 1): „«instytucja finansowa» oznacza przedsiębiorstwo inne niż instytucja, którego podstawową działalnością jest nabywanie pakietów akcji lub wykonywanie co najmniej jednego spośród rodzajów działalności wymienionych w pkt 2-12 i pkt 15 załącznika I do dyrektywy 2013/36/UE, pojęcie to obejmuje finansowe spółki holdingowe, finansowe spółki holdingowe o działalności mieszanej, instytucje płatnicze w rozumieniu dyrektywy 2007/64/WE Parlamentu Europejskiego i Rady z dnia 13 XI 2007 r. w sprawie usług płatniczych w ramach rynku) i spółki zarządzania aktywami, nie obejmuje jednak ubezpieczeniowych spółek holdingowych i ubezpieczeniowych spółek holdingowych prowadzących działalność mieszaną". 
ani przedsiębiorcą ${ }^{20} . \mathrm{Z}$ drugiej strony, wydaje się, że nie w każdym przypadku, w którym osobę fizyczną łączyć będzie określona relacja lub stosunek prawny z podmiotem rynku finansowego, możliwe będzie automatyczne jej zakwalifikowanie jako klienta w rozumieniu ustawy o Rzeczniku ${ }^{21}$. Systemowa wykładnia przepisów tego aktu może również prowadzić do wniosku, że przymiot klienta powinien być powiązany ze świadczoną przez podmiot rynku finansowego usługą. Podstawowym uprawieniem klientów wynikającym z ustawy o Rzeczniku jest prawo do wniesienia reklamacji. Zgodnie zaś z art. 2 pkt 2 tego aktu przez reklamacje rozumie się wystąpienie skierowane do podmiotu rynku finansowego przez jego klienta, w którym klient zgłasza zastrzeżenia dotyczące usług świadczonych przez ten podmiot. Okoliczność, czy i jaką usługę dany podmiot rynku finansowego świadczył, świadczy lub zamierza świadczyć osobie fizycznej, może zatem mieć znaczenie dla oceny, czy osoba taka będzie miała status klienta w rozumieniu ustawy o Rzeczniku, a w konsekwencji, czy w przypadku jej sporu z podmiotem rynku finansowego dopuszczalne będzie wydanie istotnego poglądu

${ }^{20}$ Warto dodać, że zgodnie $\mathrm{z}$ art. 4 ust. 2 ustawy o Rzeczniku „W odniesieniu do klientów, którzy nie zawarli umowy z podmiotem rynku finansowego, informacje, o których mowa w ust. 1, powinny zostać dostarczone w ciągu 7 dni od dnia, w którym nastąpiło zgłoszenie roszczeń klienta wobec podmiotu rynku finansowego". Wykładnia tego przepisu prowadzi do wniosku, że klientem w rozumieniu ustawy o Rzeczniku może być również osoba fizyczna, która nie zawarła z podmiotem rynku finansowego umowy (czynności prawnej). Taka sytuacja często będzie miała miejsce na rynku ubezpieczeniowym - np. osoby uposażone lub uprawnione z umowy ubezpieczenia nie zawsze będą jej stronami. Może też chodzić o osoby, których relacje z podmiotem rynku finansowego kształtują się dopiero na etapie przedkontraktowym - np. osoba fizyczna mogła otrzymać formularz informacyjny (art. 13 i 14 Ustawy z dnia 12 V 2011 r. o kredycie konsumenckim (Dz.U. Nr 126, poz. 715), dalej „ustawa o kredycie konsumenckim”; art. 11 Ustawy z dnia 23 III 2017 r. o kredycie hipotecznym oraz o nadzorze nad pośrednikami kredytu hipotecznego i agentami (Dz.U. poz. 819), dalej „ustawa o kredycie hipotecznym”), zawnioskować o udzielenie kredytu hipotecznego (art. 14 ust. 1 ustawy o kredycie hipotecznym) lub otrzymać decyzję kredytową (art. 14 ust. 2-8 ustawy o kredycie hipotecznym). Chodzi więc o sytuacje, w których osoba fizyczna może mieć zastrzeżenia co do usług świadczonych przez podmiot rynku finansowego, mimo że strony nie zawarły jeszcze umowy ani nie nawiązały innej relacji prawnej (czynności prawnej) w związku ze świadczoną usługą (lub usługa, która ma być świadczona w przyszłości).

${ }^{21}$ Przykładowo, wątpliwości może budzić sytuacja, w której podmiot rynku finansowego (np. instytucja pożyczkowa) emituje obligacje korporacyjne - na podstawie przepisów Ustawy z dnia 15 I 2015 r. o obligacjach (Dz.U. poz. 238 ze zm.). Nie jest jasne, czy w takim przypadku nabywca obligacji będzie klientem w rozumieniu ustawy o Rzeczniku. Wątpliwości budzi m.in. to, czy emisja obligacji stanowi świadczoną klientowi przez podmiot rynku finansowego usługę, co do której nabywca obligacji może mieć zastrzeżenia (art. 2 pkt 2 ustawy o Rzeczniku). 
w sprawie. Problematyka wykładni art. 2 ust. 1-3 ustawy o Rzeczniku zasadniczo wykracza poza ramy niniejszego opracowania, niemniej wymaga zasygnalizowania. Od tego, czy w danym sporze występuje podmiot rynku finansowego i jego klient, zależeć bowiem będzie uprawnienie Rzecznika Finansowego do wydania istotnego poglądu wszak tylko wówczas działanie Rzecznika mieścić się będzie w zakresie ochrony klientów podmiotów rynku finansowego ${ }^{22}$.

Wydaje się, że taka wykładnia przepisów ustawy o Rzeczniku w zw. z art. 63 k.p.c. stoi w zgodzie z - mającymi swoje źródło w art. 7 Konstytucji Rzeczypospolitej Polskiej ${ }^{23}$ - zasadą legalizmu (obowiązek działania na podstawie prawa) oraz zasadą praworządności (obowiązek przestrzegania prawa) ${ }^{24}$. Zasada legalizmu oznacza obowiązek określenia kompetencji do działania przez akty prawa powszechnie obowiązującego, zakaz domniemywania takich kompetencji oraz zakaz dowolnego i arbitralnego ich wykonywania ${ }^{25}$. Wyrażone w art. 7 Konstytucji RP zasady stanowią też element składowy zasady państwa prawnego ${ }^{26}$. Tym samym przypisywanie (uzurpowanie) sobie przez Rzecznika Finansowego prawa do wydawania istotnych poglądów również $\mathrm{w}$ tych sprawach, w których stronami nie byłby podmiot rynku finansowego i jego klient, mogłoby stać w sprzeczności ze wskazanymi powyżej naczelnymi zasadami konstytucyjnymi.

$\mathrm{W}$ praktyce ustalenie, czy w danej sprawie mamy do czynienia $z$ podmiotem rynku finansowego i jego klientem $w$ rozumieniu ustawy o Rzeczniku, nie zawsze będzie takie proste. Przykładowo, pojawiają się wątpliwości w przypadku cesji (przelewu) wierzytelności wynikających z umów zawartych przez podmioty rynku finansowego z ich

\footnotetext{
${ }^{22}$ Artykuł 1 w zw. z art. 17, w zw. z art. 28 ustawy o Rzeczniku, w zw. z art. 63 k.p.c.

${ }^{23}$ Konstytucja Rzeczypospolitej Polskiej z dnia 2 IV 1997 r. (Dz.U. Nr 78, poz. 483 ze zm.), dalej „Konstytucja RP”.

${ }^{24}$ P. Tuleja, Komentarz do art. 7, w: Konstytucja RP, t. 1: Komentarz do art. 1-86, pod red. M. Safjana, L. Boska, Warszawa 2016.

${ }^{25}$ Ibidem. Zob. też wyrok Trybunału Konstytucyjnego (TK) z 14 VI 2006 r., sygn. K 53/05, OTK-A 2006, nr 6, poz. 660, w którym stwierdzono, że „stosownie do art. 7 Konstytucji, organy władzy publicznej działają na podstawie i w granicach prawa. Oznacza to m.in., że kompetencje organów władzy publicznej powinny zostać jednoznacznie i precyzyjnie określone w przepisach prawa, wszelkie działania tych organów powinny mieć podstawę $\mathrm{w}$ takich przepisach, $\mathrm{a}-\mathrm{w}$ razie wątpliwości interpretacyjnych - kompetencji organów władzy publicznej nie można domniemywać. Zasady te odnoszą się w szczególności do kompetencji organów administracji publicznej prowadzących postępowania w sprawach podatkowych".

${ }^{26}$ P. Tuleja, op. cit.
} 
klientami ${ }^{27}$. Na rynku finansowym przelew wierzytelności jest częstą praktyką i zwykle ma miejsce wówczas, gdy klient (dłużnik) nie wykonuje lub nienależycie wykonuje - przynajmniej w ocenie podmiotu rynku finansowego - swoje zobowiązania. Zgodnie z przepisami Kodeksu cywilnego ${ }^{28}$ przelew wierzytelności na osobę trzecią może nastąpić bez zgody dłużnika, chyba że sprzeciwiałoby się to ustawie, zastrzeżeniu umownemu albo właściwości zobowiązania ${ }^{29}$. Umowy na rynku finansowym, zwłaszcza jeśli zawierane są z konsumentami na zasadzie adhezji, generalnie nie przewidują wyłączenia prawa wierzyciela do przelewu wierzytelności. Wraz z wierzytelnością przechodzą na nabywcę wszelkie związane z nią prawa, w szczególności roszczenie o zaległe odsetki ${ }^{30}$. Natomiast dłużnikowi przysługują przeciwko nabywcy wierzytelności wszelkie zarzuty, które miał przeciwko zbywcy $\mathrm{w}$ chwili powzięcia wiadomości o przelewie ${ }^{31}$. Celem takiej regulacji jest

${ }^{27}$ Częsty problem stanowi sytuacja, kiedy fundusz inwestycyjny nabywa w drodze cesji (przelewu) wierzytelność dłużnika. Zgodnie z brzmieniem art. 2 pkt 3 lit. c ustawy o Rzeczniku do podmiotów rynku finansowego zalicza się m.in. towarzystwo funduszy inwestycyjnych i fundusz inwestycyjny. Przepis ten powinien być jednak interpretowany w związku z treścią art. 2 pkt 1 lit. d ustawy o Rzeczniku, zgodnie z którym klientem podmiotu rynku finansowego jest $\mathrm{m}$.in. uczestnik funduszu inwestycyjnego. Definicja uczestnika funduszu inwestycyjnego zawarta jest w art. 6 ust. 1 Ustawy z dnia 27 V 2004 r. o funduszach inwestycyjnych i zarządzaniu alternatywnymi funduszami inwestycyjnymi (Dz.U. 2014, poz. 157 ze zm.), dalej "ustawa o funduszach inwestycyjnych”, zgodnie z którym "Uczestnikami funduszu inwestycyjnego są osoby fizyczne, osoby prawne i jednostki organizacyjne nieposiadające osobowości prawnej: 1) na rzecz których w rejestrze uczestników funduszu są zapisane jednostki uczestnictwa lub ich ułamkowe części albo 2) będące posiadaczami rachunku papierów wartościowych, na którym są zapisane certyfikaty inwestycyjne, albo będące osobami uprawnionymi z certyfikatów inwestycyjnych zapisanych na rachunku zbiorczym, albo 3) uprawnione z certyfikatów inwestycyjnych $\mathrm{w}$ formie dokumentu, albo 4) wskazane w ewidencji uczestników funduszu jako posiadacze certyfikatów inwestycyjnych, które nie mają formy dokumentu". W przypadku cesji wierzytelności fundusz inwestycyjny ma, co prawda, status podmiotu rynku finansowego, o którym mowa w art. 2 ust. 3 lit. c ustawy o Rzeczniku, jednakże dłużnik nie ma statusu klienta podmiotu rynku finansowego, o którym mowa w art. 2 pkt 1 lit. d tego aktu - nie spełnia bowiem przesłanek określonych w art. 6 ust. 1 ustawy o funduszach inwestycyjnych.

${ }^{28}$ Ustawa z dnia 23 IV 1964 r. - Kodeks cywilny (Dz.U. Nr 16, poz. 93 ze zm.), dalej „k.c.”.

${ }^{29}$ Artykuł 509 § 1 k.c.

${ }^{30}$ Artykuł 509 § 2 k.c.

${ }^{31}$ Artykuł 513 § 1 k.c. Natomiast zgodnie z art. 513 § 2 k.c. „[d]łużnik może z przelanej wierzytelności potrącić wierzytelność, która mu przysługuje względem zbywcy, chociażby stała się wymagalna dopiero po otrzymaniu przez dłużnika zawiadomienia o przelewie. Nie dotyczy to jednak wypadku, gdy wierzytelność przysługująca względem zbywcy stała się wymagalna później niż wierzytelność będąca przedmiotem przelewu". 
zapewnienie, aby przelew wierzytelności - dokonywany przecież bez zgody dłużnika - nie mógł pogarszać jego sytuacji wobec wierzyciela, bez względu na to, że przymiot ten uzyskała inna osoba ${ }^{32}$. Pytanie jednak, czy na tej podstawie można przyjąć, iż Rzecznikowi Finansowemu przysługują kompetencje ( $w$ tym uprawnienie do przedstawienia istotnego poglądu) w sprawie, w której będący stroną postępowania nabywca wierzytelności nie jest podmiotem rynku finansowego, jeżeli jej zbywca taki przymiot miał i jeżeli dodatkowo dłużnik był klientem zbywcy jako podmiotu rynku finansowego. Ponadto, nawet w tych wypadkach, w których nabywca wierzytelności również byłby podmiotem rynku finansowego, nie zawsze będzie to automatycznie oznaczać, że w zakresie relacji wynikającej z nabytej wierzytelności dłużnik uznany zostanie za klienta tego podmiotu w rozumieniu ustawy o Rzeczniku ${ }^{33}$.

Przyznać trzeba, że przyjęcie w omawianych sytuacjach, iż Rzecznik Finansowy nie jest uprawniony do wydania istotnego poglądu w sprawie, może prowadzić do osłabienia sytuacji procesowej dłużnika, co z pewnością byłoby sprzeczne z ratio legis art. $513 \S 1$ k.c. ${ }^{34}$ Istotny pogląd mógłby bowiem zawierać oświadczenia wiedzy lub oceny korzystne dla dłużnika i niepozostające bez znaczenia dla rozstrzygnięcia sprawy. Co

${ }^{32}$ K. Zagrobelny, Komentarz do art. 513, w: Kodeks cywilny. Komentarz, pod red. E. Gniewka, P. Machnikowskiego, Warszawa 2017.

${ }^{33}$ Teoretycznie można sobie wyobrazić także sytuację, w której nabywcą wierzytelności będzie podmiot rynku finansowego, przy czym niezależnie od nabytej wierzytelności nabywca będzie pozostawał $\mathrm{z}$ dłużnikiem w odrębnej relacji (na podstawie odrębnego stosunku prawnego), a więc w związku z inną usługa, czyniąc go na tej podstawie klientem w rozumieniu ustawy o Rzeczniku. Również w takim wypadku wydaje się, że $\mathrm{w}$ zakresie sporu wynikającego $\mathrm{z}$ nabytej przez podmiot rynku finansowego wierzytelności dłużnika trudno będzie zakwalifikować jako klienta nabywcy (choć będzie on klientem nabywcy jako podmiotu rynku finansowego ze względu na odrębny od nabytej wierzytelności stosunek prawny łączący strony).

${ }^{34}$ Wyjątek może stanowić sytuacja, w której np. nabywca wierzytelności odroczy dłużnikowi odpłatnie termin spełnienia świadczenia pieniężnego, co może być kwalifikowane jako rodzaj umowy o kredyt konsumencki (art. 3 ust. 2 pkt 3 ustawy o kredycie konsumenckim). W konkretnych okolicznościach możliwe byłoby wówczas przyjęcie, że wierzyciel stanowi instytucję pożyczkową w rozumieniu art. 2 pkt 3 lit. h ustawy o Rzeczniku (a więc podmiot rynku finansowego), dłużnik zaś - klienta takiego podmiotu (art. 2 pkt 1 lit. d ustawy o Rzeczniku). W takim wypadku należałoby uznać, że Rzecznikowi Finansowemu przysługuje kompetencja do wydania istotnego poglądu. Uprawnienie to wynikałoby jednak z faktu świadczonej przez nabywcę wierzytelności usługi polegającej na odpłatnym odroczeniu płatności, nie zaś z faktu samego nabycia na podstawie umowy przelewu wierzytelności wynikającej z umowy (czynności prawnej) zawartej uprzednio przez zbywcę z dłużnikiem. 
prawda, w art. $513 \S 1$ k.c. mowa jest o wszelkich zarzutach, a zatem przepis ten należy interpretować szeroko, niemniej trudno uznać, że prawo Rzecznika Finansowego do wydania istotnego poglądu stanowi zarzut dłużnika w rozumieniu materialnych lub proceduralnych przepisów prawa cywilnego. Uprawnienie w tym zakresie ma przecież charakter publicznoprawny. Warto też podkreślić, że jest to uprawnienie Rzecznika Finansowego, nie zaś dłużnika. Ten może jedynie zwrócić się do Rzecznika z wnioskiem o wydanie istotnego poglądu, który nie jest jednak dla Rzecznika wiążący.

Taka wykładnia może być także rozpatrywana jako sprzeczna z ratio legis ustawy o Rzeczniku, jakim jest przecież szeroka ochrona osób fizycznych korzystających $z$ usług finansowych ${ }^{35}$. Ponadto może prowadzić do łatwego obchodzenia przepisów przywołanego aktu w tym zakresie. Wystarczy, że podmiot rynku finansowego chcący uniknąć ewentualnego istotnego poglądu w sporze $\mathrm{z}$ klientem dokona przelewu wierzytelności na podmiot trzeci. Tymczasem wówczas w istocie brak jest racjonalnego uzasadnienia, aby wyłączać kompetencję Rzecznika Finansowego do przedstawienia istotnego poglądu. Jego treść - jeżeli zostałby wydany - byłaby przecież taka sama jak w przypadku, w którym spór toczyłby się pomiędzy podmiotem rynku finansowego, który dokonał przelewu wierzytelności, a jego klientem. Co najwyżej mogłaby zostać rozszerzona o kwestie związane z samą umową przelewu ${ }^{36}$.

${ }^{35} \mathrm{~W}$ polskim prawie brak jest definicji legalnej usług finansowych. Do tego pojęcia odwołuje się natomiast np. Ustawa z dnia 30 V 2014 r. o prawach konsumenta (Dz.U. poz. 827), dalej „ustawa o prawach konsumenta”. Zgodnie z art. 4 ust. 2 tego aktu „Przepisów ustawy nie stosuje się do umów dotyczących usług finansowych, w szczególności takich jak: czynności bankowe, umowy kredytu konsumenckiego, czynności ubezpieczeniowe, umowy nabycia lub odkupienia jednostek uczestnictwa funduszu inwestycyjnego otwartego albo specjalistycznego funduszu inwestycyjnego otwartego i nabycia lub objęcia certyfikatów inwestycyjnych funduszu inwestycyjnego zamkniętego, usługi płatnicze - z wyjątkiem umów dotyczących usług finansowych zawieranych na odległość, do których stosuje się przepisy rozdziałów 1 i 5". Przepis ten nie definiuje pojęcia usługi finansowej, ale zawiera przykładowy (otwarty) katalog czynności lub umów stanowiących usługi finansowe.

${ }^{36}$ Artykuł 513 k.c. stanowi o możliwości podniesienia zarzutów, które przysługiwały dłużnikowi przeciwko cedentowi zbywanej wierzytelności. W doktrynie przedmiotem rozważań było pytanie o możliwość podniesienia zarzutów dotyczących samej umowy cesji. Wydaje się, że przeważa pogląd, iż podniesienie takich zarzutów jest dopuszczalne, niemniej nie na podstawie "analogicznie" czy „odpowiednio" stosowanego art. 513 k.c., lecz na zasadach ogólnych (zob. K. Mularski, Komentarz do art. 513, w: Kodeks cywilny, t. 2: Komentarz. Art. 450-1088, pod red. M. Gutowskiego, Warszawa 2016, i przytoczone tam wypowiedzi doktryny). 
W tym kontekście warto też zaznaczyć, że w niektórych miejscach ustawa o Rzeczniku odwołuje się nie tylko do podmiotów rynku finansowego i ich klientów, ale do rynku finansowego w ogólności ${ }^{37}$. Mogłoby to stanowić argument za szerszym ujmowaniem kompetencji Rzecznika Finansowego, w tym za dopuszczeniem możliwości wydania istotnego poglądu $\mathrm{w}$ danej sprawie, jeżeli dotyczy ona szeroko rozumianego rynku finansowego, nawet jeżeli w ujęciu formalnym stronami sporu nie byłyby podmiot rynku finansowego i jego klient ${ }^{38}$. Biorąc jednak pod uwagę treść obowiązujących przepisów oraz doniosłość zasady legalizmu, mającej charakter naczelnej zasady konstytucyjnej, wydaje się, że możliwość wydania istotnego poglądu w sprawie, w której stronami nie są podmiot rynku finansowego i jego klient, obecnie można rozpatrywać co najwyżej w charakterze postulatu de lege ferenda.

Podobne wątpliwości może budzić pytanie, czy spadkobierca lub spadkobiercy klienta podmiotu rynku finansowego stają się z chwilą jego śmierci klientami tego podmiotu. Zgodnie z podstawową zasadą prawa spadkowego na spadkobierców przechodzą zarówno prawa, jak i obowiązki majątkowe zmarłego ${ }^{39}$. Jeżeli zatem spadkobiorcom klienta podmiotu rynku finansowego przysługują określone prawa lub roszczenia wobec tego podmiotu, bądź też ciążą na nich względem tego podmiotu określone obowiązki, to nie należałoby a priori wykluczać możliwości uznania, że również tacy spadkobiercy mogą mieć przymiot klienta podmiotu rynku finansowego w rozumieniu ustawy

${ }^{37} \mathrm{Na}$ przykład w art. 13 pkt 1, art. 17 ust. 1 pkt 4, art. 19 ust. 3, art. 25 ust. 1 pkt 3 ustawy o Rzeczniku. Zob. też Uzasadnienie do poselskiego projektu ustawy o rozpatrywaniu reklamacji przez podmioty rynku finansowego i o Rzeczniku Finansowym (druk nr 3430/VII kadencja), s. 16, http://www.sejm.gov.pl/sejm7.nsf/druk.xsp?nr=3430 (dostęp: 21 II 2018).

${ }^{38} \mathrm{~W}$ konkretnych okolicznościach, np. gdyby przemawiał za tym ważny interes społeczny, można by ewentualnie rozważyć istnienie kognicji Rzecznika Finansowego, a w konsekwencji również jego kompetencji do wydania istotnego poglądu w tych sprawach, w których jedną ze stron byłby podmiot rynku finansowego, nawet jeżeli drugą nie byłby jego klient - np. w sprawie, w której fundusz inwestycyjny dochodziłby roszczeń wynikających z nabytej na mocy umowy przelewu wierzytelności od osoby fizycznej niebędącej uczestnikiem tego funduszu. Taka wykładnia wymagałaby jednak dużej ostrożności, gdyż taki tok rozumowania mógłby prowadzić choćby do wniosku, że wydanie istotnego dla sprawy poglądu możliwe byłoby także $\mathrm{w}$ przypadku sporu między dwoma podmiotami rynku finansowego, co byłoby jednak w oczywisty sposób nie do pogodzenia z literą i celami ustawy o Rzeczniku.

${ }^{39}$ Artykuł 922 § 1 k.c. Zgodnie z art. 924 k.c. „[s]padek otwiera się z chwilą śmierci spadkodawcy". Natomiast zgodnie z art. 925 k.c. "[s]padkobierca nabywa spadek z chwilą otwarcia spadku". 
o Rzeczniku. Za taką wykładnią może przemawiać szeroka definicja klienta podmiotu rynku finansowego, ratio legis przywołanego aktu oraz fakt, że w świetle treści art. 4 ust. 2 ustawy o Rzeczniku klientem podmiotu rynku finansowego może być również osoba fizyczna, która w ogóle nie zawarła z tym podmiotem umowy, lecz przysługują jej lub zgłasza ona względem takiego podmiotu roszczenia.

Powyższe pokazuje, że w niektórych przypadkach mogą się pojawić wątpliwości, czy Rzecznikowi Finansowemu przysługiwać będzie kompetencja do podjęcia działań, w tym uprawnienie do przedstawienia sądowi istotnego dla sprawy poglądu ${ }^{40}$. Wydaje się, że decydujące znaczenie będą miały okoliczności konkretnej sprawy i pytanie, czy wynikać z nich będzie konieczność ochrony praw lub interesów klientów podmiotów rynku finansowego. Granicę działań Rzecznika Finansowego wyznaczać będzie natomiast wskazana wcześniej konstytucyjna zasada legalizmu.

\section{Osoby umocowane do wyrażenia istotnego poglądu}

Warto również pokrótce odnieść się do kwestii tego, które osoby mogą zostać umocowane do wyrażenia istotnego poglądu. Rzecznik Finansowy jako organ niekolegialny z istoty nie podejmuje uchwał. Ustawa o Rzeczniku nie wskazuje także organów umocowanych do reprezentowania Rzecznika Finansowego, który zgodnie z art. 16 ust. 1 tego aktu ma osobowość prawną. Natomiast stosownie do art. 18 ust. 1 i art. 19 ust. 1 ustawy o Rzeczniku Rzecznik Finansowy wykonuje swoje zadania przy pomocy odpowiednio podległego mu Biura Rzecznika oraz nie więcej niż trzech zastępców. Wydaje się, iż odpowiednie stosowanie w omawianym zakresie art. 63 k.p.c. oznacza, że istotny pogląd może zostać wyrażony w oświadczeniu samego Rzecznika Finansowego, a w odpowiednich przypadkach również przez jego zastępców. Uzasadnione względami praktycznymi wydaje się także dopuszczenie możliwości wyrażenia istotnego poglądu przez upoważnionych pracowników Biura Rzecznika Finansowego ${ }^{41}$. Wychodząc z takich założeń, należałoby przyjąć, że

${ }^{40}$ Wątpliwości może budzić np., czy klientem w rozumieniu ustawy o Rzeczniku będzie poręczyciel zobowiązujący się wobec podmiotu rynku finansowego (wierzyciela) wykonać zobowiązanie na wypadek, gdyby klient (dłużnik) zobowiązania nie wykonał. Podobne wątpliwości mogą się pojawić w odniesieniu do dłużnika hipotecznego.

${ }^{41} \mathrm{~W}$ tym zakresie znaczenie dla wykładni art. 28 ustawy o Rzeczniku w zw. z art. 63 k.p.c. będzie miało Zarządzenie nr 127 Prezesa Rady Ministrów z dnia 26 X 2015 r. w sprawie nadania statutu Biuru Rzecznika Finansowego (M.P. poz. 1055, t. 1), dalej „zarządzenie”. 
istotny pogląd może zostać wyrażony w oświadczeniu Rzecznika Finansowego, upoważnionych do tego zastępców Rzecznika lub pracowników Biura Rzecznika Finansowego, o których mowa w zarządzeniu.

\section{Procedura związana z rozpatrzeniem wniosku o wydanie istotnego poglądu}

Treść art. 28 ustawy o Rzeczniku w zw. z art. 63 k.p.c. nie powinna pozostawiać wątpliwości, że wyrażenie istotnego poglądu jest uprawnieniem, nie zaś obowiązkiem Rzecznika Finansowego. Taki pogląd znajduje również potwierdzenie w orzecznictwie Sądu Najwyższego $(\mathrm{SN})^{42}$. Warto podkreślić, że inicjatywa Rzecznika Finansowego do wydania istotnego poglądu nie wymaga wniosku ani zgody sądu ${ }^{43}$. Równocześnie sąd nie może wezwać (zażądać) ani też zobowiązać Rzecznika Finansowego do wyrażenia istotnego poglądu ${ }^{44}$. Sąd może natomiast zwrócić się do

Wynika z niego, że Rzecznik kieruje Biurem przy pomocy zastępców oraz osób kierujących komórkami organizacyjnymi Biura ( $\$ 3$ ust. 1 i $\S 4$ zarządzenia). Zakres zadań zastępców oraz osób kierujących komórkami organizacyjnymi Biura określa Rzecznik Finansowy ( 33 ust. 2 zarządzenia). Rzecznik Finansowy może też upoważnić zastępców Rzecznika, osoby kierujące komórkami organizacyjnymi Biura oraz innych pracowników Biura zatrudnionych na stanowiskach koordynujących lub samodzielnych do działania w imieniu Rzecznika w określonych przez niego sprawach ( 33 ust. 3 zarządzenia).

${ }^{42}$ Wyrok SN z 11 XII 1980 r., sygn. I PR 62/80, Legalis nr 22393.

${ }^{43} \mathrm{~W}$ doktrynie wskazuje się, iż ", $[\mathrm{w}]$ tym kierunku poszła praktyka, przyjmując, że organizacja społeczna może przedstawić pogląd bądź z własnej inicjatywy, bądź na żądanie sądu" (M. Sychowicz, Komentarz do art. 63, w: Kodeks postępowania cywilnego, t. 1: Komentarz. Art. 1-366, pod red. K. Piaseckiego, Warszawa 2016). Podobnie K. Flaga-Gieruszyńska, Komentarz do art. 63, w: Kodeks postępowania cywilnego. Komentarz, pod red. A. Zielińskiego, K. Flagi-Gieruszyńskiej, Warszawa 2017. Autorka stwierdza, iż "[t]reść komentowanego przepisu jasno wskazuje, że przedstawienie poglądu istotnego dla sprawy jest uprawnieniem organizacji pozarządowej, i nie wiąże tego uprawnienia z jakimikolwiek kompetencjami innego podmiotu. Należy uznać, że w takim przypadku aktywność sądu ogranicza się do stwierdzenia, czy dana organizacja pozarządowa należy do kręgu uprawnionych, a w razie negatywnej odpowiedzi na ten problem - odmówienia możliwości przedstawienia poglądu poprzez wydanie właściwej treści postanowienia, na które zażalenie nie przysługuje".

${ }^{44} \mathrm{~W}$ doktrynie wskazuje się, że "[w] razie niezgłoszenia poglądu żądanego przez sąd nie można stosować względem niej [organizacji] środków przymusu" (M. Uliasz, Komentarz do art. 63, w: idem, Kodeks postępowania cywilnego. Komentarz, 2008). Per analogiam stwierdzenie to odnosić się będzie również do Rzecznika Finansowego. Podobnie K. Flaga-Gieruszyńska, op. cit. Autorka stwierdza, iż "[z] uwagi na to, że jest to uprawnienie organizacji, wydaje się, że sąd nie ma instrumentów procesowych mogących przymusić organizację do przedstawienia takiej opinii". 
Rzecznika Finansowego o rozważenie możliwości wyrażenia istotnego poglądu po uprzedniej analizie sprawy. W tym celu powinien udostępnić Rzecznikowi akta sprawy w zakresie koniecznym do rozpatrzenia możliwości wyrażenia istotnego poglądu. Również klient podmiotu rynku finansowego ma jedynie prawo złożenia wniosku o wydanie istotnego poglądu w sprawie. Odmowa wyrażenia poglądu, zwłaszcza jeżeli sprawa objęta jest zakresem kompetencji Rzecznika Finansowego, powinna być należycie uzasadniona ${ }^{45}$. Jeżeli natomiast wniosek zawiera braki, np. nie zostanie podpisany przez wnioskodawcę bądź nie zawiera informacji lub dokumentów koniecznych do wszechstronnej analizy sprawy, Rzecznik Finansowy powinien wezwać wnioskodawcę do ich uzupełnienia, jednocześnie wskazując, o jakie braki chodzi. W odpowiednim zakresie może także rozważyć - zwłaszcza jeżeli wnioskuje o to klient - zwrócenie się do sądu o udostępnienie akt sprawy na podstawie art. $63^{5}$ k.p.c.

Zasadniczo, istotny pogląd powinien zostać wyrażony w oświadczeniu mającym charakter formy pisemnej (wyjątek stanowi sytuacja, kiedy sąd na wniosek Rzecznika Finansowego zezwoli, aby pogląd został przedstawiony ustnie na rozprawie - odpowiednie stosowanie art. $63^{5} \S 1$ k.p.c.). W tym kontekście nie należy wykluczać możliwości uzupełnienia poglądu, gdyby okazało się to konieczne lub uzasadnione, aczkolwiek nie powinno to prowadzić do sytuacji, w której Rzecznik Finansowy miałby przyjąć status strony (quasi-strony) procesu lub też pełnić rolę pełnomocnika jednej ze stron ${ }^{46}$. Wytoczenie powództwa

${ }^{45}$ Biorąc pod uwagę postulat, aby istotny pogląd miał obiektywny charakter, odmowa jego wydania najczęściej będzie miała miejsce - poza wypadkami, w których Rzecznik Finansowy uzna brak swojej kompetencji w sprawie - jeżeli jego treść miałaby się okazać dla klienta niekorzystna. Zadaniem Rzecznika Finansowego jest bowiem ochrona praw i interesów klientów. Jeżeli mimo zwrócenia się przez sąd lub klienta o przedstawienie poglądu istotnego dla sprawy Rzecznik takowego nie przedstawi, możliwe jest rozważenie powiadomienia odpowiednich organów, gdyby odmowa wyrażenia poglądu wskazywała na uchylanie się od wykonywania ustawowych obowiązków, w szczególności gdyby odmowa wyrażenia istotnego poglądu nie została uzasadniona lub została uzasadniona nienależycie. W tym kontekście należy, po pierwsze, wspomnieć o wynikającym z art. 34 ustawy o Rzeczniku obowiązku corocznego składania Prezesowi Rady Ministrów sprawozdania ze swojej działalności oraz uwag o stanie przestrzegania prawa i interesów klientów podmiotów rynku finansowego. Po drugie, zgodnie z art. 14 ustawy o Rzeczniku, Prezes Rady Ministrów, na wniosek ministra właściwego do spraw instytucji finansowych, może odwołać Rzecznika przed upływem kadencji. Odwołanie może nastąpić tylko i wyłącznie z powodów wymienionych w art. 15 ustawy o Rzeczniku.

${ }^{46}$ W wyroku z 11 XII 1980 r., sygn. I PR 62/80, Legalis nr 22393, SN wskazał, że „[p]rzedstawienie przez organizację poglądu nie wywołuje bezpośredniego udziału organizacji w postępowaniu rozpoznawczym. Brak jest więc podstaw prawnych do 
lub wzięcie przez Rzecznika Finansowego udziału w toczącym się już postępowaniu możliwe jest jedynie na podstawie i w sytuacji określonej w art. 26 ustawy o Rzeczniku ${ }^{47}$. Artykuł 63 k.p.c. jasno wskazuje, że uprawnienie do wyrażenia istotnego poglądu przysługuje Rzecznikowi Finansowemu tylko i wyłącznie wówczas, jeżeli nie uczestniczy on w sprawie. Dlatego w tych sprawach, w których Rzecznik skorzystał, zamierza skorzystać lub rozważa skorzystanie z uprawnienia, o którym mowa w art. 26 ustawy o Rzeczniku, nie powinien wyrażać istotnego poglądu. Czynny udział w sprawie na zasadach wynikających z art. 26 ustawy o Rzeczniku w zw. z art. 55-60 k.p.c. stanowi bowiem instrument odrębny od istotnego poglądu uregulowanego w art. 63 k.p.c., który stosuje się odpowiednio do Rzecznika Finansowego na podstawie art. 28 ustawy o Rzeczniku. Wytoczenie powództwa lub udział w toczącej się już sprawie wyklucza zatem możliwość wyrażenia istotnego poglądu, i odwrotnie, jego wyrażenie wyklucza możliwość wniesienia powództwa lub udziału w sprawie. W tym kontekście klient lub sąd powinien szczegółowo rozważyć, o jakie działanie Rzecznika Finansowego w sprawie wnosi. Również Rzecznik Finansowy powinien dokonać analizy, która instytucja - udział w sprawie czy wyrażenie istotnego poglądu - będzie bardziej uzasadniona w danych okolicznościach.

Istotny pogląd może zostać wyrażony każdemu sądowi ${ }^{48}$, na każdym etapie postępowania ${ }^{49}$. Wydaje się, że na podstawie art. $13 \S 2$

wezwania w takiej sytuacji organizacji społecznej na rozprawę, a tym bardziej brak jest podstaw do wezwania na rozprawę, gdy organizacja nie przekaże sądowi poglądu. Jeżeli organizacja społeczna chce bezpośrednio uczestniczyć w postępowaniu rozpoznawczym z samodzielną legitymacją - art. 61 par. 2 KPC daje ku temu podstawę prawną".

${ }^{47}$ Warto przy tym dodać, że ustawodawca ograniczył zakres kompetencji Rzecznika Finansowego wynikającej z art. 26 ustawy o Rzeczniku wyłącznie do spraw dotyczących nieuczciwych praktyk rynkowych, a więc materii zasadniczo uregulowanej w u.p.n.p.r. Ustawa ta w zakresie podmiotowym ma na celu ochronę konsumentów, gdyż nieuczciwy charakter określonej praktyki rynkowej może się aktualizować tylko i wyłącznie, jeżeli praktyka skierowana będzie przez przedsiębiorcę wobec konsumenta lub konsumentów. Oznacza to, że kompetencja Rzecznika Finansowego wynikająca z art. 26 ustawy o Rzeczniku - jakkolwiek w przepisie tym mowa jest o kliencie podmiotu rynku finansowego - ograniczona jest do tych przypadków, w których klientem jest osoba fizyczna będąca konsumentem. Wynika to z systemowej wykładni art. 26 ustawy o Rzeczniku i przepisów u.p.n.p.r.

${ }^{48}$ Mowa tu o sądzie rejonowym, sądzie okręgowym, sądzie apelacyjnym i Sądzie Najwyższym.

${ }^{49} \mathrm{~W}$ doktrynie wskazuje się, że istotny pogląd może zostać wyrażony przed sądem I i II instancji, przed SN - w postępowaniu toczącym się na skutek wniesienia skargi kasacyjnej, w postępowaniu toczącym się na skutek wznowienia postępowania, w postępowaniu prowadzonym na skutek skargi o stwierdzenie niezgodności z prawem 
k.p.c. istnieje możliwość przedstawienia istotnego poglądu również $\mathrm{w}$ postępowaniu nieprocesowym, niemniej w kontekście kompetencji Rzecznika Finansowego wydaje się mało prawdopodobne, aby sprawa (spór) klienta z podmiotem rynku finansowego rozpatrywana była $\mathrm{w}$ postępowaniu nieprocesowym ${ }^{50}$.

Nie powinno budzić wątpliwości, że procedura związana z analizą wniosku o wydanie istotnego poglądu nie stanowi postępowania administracyjnego ${ }^{51}$, sam zaś istotny pogląd nie ma charakteru decyzji administracyjnej - wydaje się, że istotny pogląd powinien czynić zadość wymogom formalnym pisma procesowego przewidzianym w art. 126 i n. k.p.c. Zasadność takiego poglądu wynika z faktu, iż działania podejmowane przez Rzecznika Finansowego w tym zakresie nie mają charakteru władczego ${ }^{52}$. Uprawnienia i obowiązki klientów podmiotów rynku finansowego wynikają bowiem z czynności prawnych (najczęściej umów) i przepisów prawa powszechnie obowiązującego. Czynności i działania Rzecznika Finansowego nie mają w tym zakresie żadnego bezpośredniego wpływu na sytuację prawną klientów. Innymi słowy, Rzecznikowi Finansowemu nie przysługują żadne instrumenty, którymi mógłby władczo kształtować prawa lub obowiązki podmiotów rynku finansowego i ich klientów. W szczególności Rzecznik Finansowy nie jest władny kształtować relacji między podmiotami rynku finansowego a ich klientami ${ }^{53}$. Działania lub czynności Rzecznika Finansowego podejmowane na podstawie art. 17, art. 24-30 oraz art. 35-43 ustawy

prawomocnego orzeczenia, a także w postępowaniu toczącym się na skutek przedstawienia do rozstrzygnięcia zagadnienia prawnego powstałego w konkretnej sprawie lub na skutek wniosku o rozstrzygnięcie wątpliwości, które ujawniły się w orzecznictwie sądów powszechnych, sądów wojskowych lub SN (M. Sychowicz, op. cit.).

${ }^{50} \mathrm{~W}$ doktrynie wskazuje się, że istotny pogląd może zostać wydany przez organizację społeczną w każdej sprawie cywilnej (K. Flaga-Gieruszyńska, op. cit.).

${ }^{51} \mathrm{~W}$ praktyce istotny pogląd najczęściej wydawany jest na wniosek klienta podmiotu rynku finansowego lub sądu, choć Rzecznik Finansowy nie jest takimi wnioskami związany. W tym sensie w zasadzie każdy istotny pogląd wydawany jest z urzędu. Wniosek stanowi zaś informację powziętą przez Rzecznika Finansowego o toczącym się postępowaniu, czego konsekwencją może, ale nie musi, być wydanie istotnego poglądu dla sprawy. Nie sposób również wykluczyć sytuacji, w której istotny pogląd wydany zostanie w następstwie wniosku przedłożonego przez podmiot rynku finansowego lub podmiot trzeci.

${ }^{52}$ Warto zresztą dodać, że wszelkie działania podejmowane przez Rzecznika Finansowego na podstawie art. 17, art. 24-30 oraz art. 35-43 ustawy o Rzeczniku nie mają charakteru władczego.

${ }^{53}$ Rzecznik Finansowy nie korzysta zatem w tej sytuacji z przymiotu władztwa administracyjnego. 
o Rzeczniku nie są więc objęte dyspozycją norm zawartych w art. 1 i 2 Kodeksu postępowania administracyjnego ${ }^{54}$, a tym samym nie są one normowane przepisami k.p.a. W konsekwencji należy uznać, że ustawa o Rzeczniku - z pewnymi wyjątkami ${ }^{55}$ - nie przewiduje uprawnienia Rzecznika Finansowego do wydawania aktów administracyjnych wskazanych w art. 3 \& 2 pkt 1-7 Prawa o postępowaniu przed sądami administracyjnymi ${ }^{56}$. Tym samym działania i czynności podejmowane w omawianym zakresie przez Rzecznika Finansowego nie są również objęte dyspozycją normy zawartej w art. 3 § 1 i 2 pkt 8 i 9 p.p.s.a. ${ }^{57}$ Stanowisko takie znajduje też odzwierciedlenie w orzecznictwie sądów administracyjnych ${ }^{58}$.

${ }^{54}$ Ustawa z dnia 14 VI 1960 r. Kodeks postępowania administracyjnego (Dz.U. Nr 30, poz. 168 ze zm.), dalej „k.p.a.”.

${ }^{55}$ Wyjątek stanowi art. 32 ustawy o Rzeczniku, zgodnie z którym „[n]a podmiot rynku finansowego, który narusza obowiązki nałożone w art. 4 ust. 1, art. 6-10, art. 30 i art. 31, Rzecznik może, w drodze decyzji, nałożyć karę pieniężną do wysokości 100000 zł". Inny wyjątek może stanowić sytuacja, w której Rzecznik Finansowy wydaje decyzję o odmowie ujawnienia informacji publicznej na podstawie przepisów u.o.d.i.p.

${ }^{56}$ Ustawa z dnia 30 VIII 2002 r. Prawo o postępowaniu przed sądami administracyjnymi (Dz.U. Nr 153, poz. 1270 ze zm.), dalej „p.p.s.a.”.

${ }^{57}$ W szczególności czynności podejmowane przez Rzecznika Finansowego nie spełniają dyspozycji art. 3 \& 2 pkt 4 p.p.s.a. Przepis ten umożliwia zaskarżalność innej grupy aktów administracyjnych (takich, które nie są decyzjami administracyjnymi lub postanowieniami), które dotyczą uprawnień lub obowiązków wynikających z przepisów prawa. W doktrynie wskazuje się, że „[z]akres przedmiotowy aktów dotyczących uprawnień lub obowiązków wynikających z przepisów prawa należy ograniczyć do przepisów materialnego prawa administracyjnego, które wyłączają możliwość wydania decyzji czy postanowienia, wymagają jednak od organu wykonującego administrację publiczną potwierdzenia obowiązku lub uprawnienia. [...] Podstawowe znaczenie dla przeprowadzenia przedmiotowej delimitacji pomiędzy aktami dającymi się przyporządkować kognicji sądów administracyjnych na podstawie art. $3 \S 2$ pkt 4 p.p.s.a. ma więc to, czy norma prawa administracyjnego wymaga konkretyzacji przy wykorzystaniu sformalizowanej procedury administracyjnej (na przykład k.p.a.). [...] Należy bez wątpienia wyłączyć przepisy prawa, które kształtują uprawnienia lub obowiązki bezpośrednio z mocy prawa. [...] Dyspozycją normy zawartej w art. $3 \S 2$ pkt 4 p.p.s.a. objęte są zatem tylko takie akty lub czynności organów administracji publicznej, których przedmiotem jest przyznanie (odmowa przyznania), stwierdzenie (odmowa stwierdzenia) albo uznanie (odmowa uznania) określonego uprawnienia lub obowiązku wynikających z mocy powszechnie obowiązującego przepisu prawa" (J. Drachal, J. Jagielski, R. Stankiewicz, Komentarz do art. 3, w: Prawo o postepowaniu przed sadami administracyjnymi. Komentarz, pod red. R. Hausera, M. Wierzbowskiego, Warszawa 2017).

${ }^{58}$ Zob.: postanowienie Naczelnego Sądu Administracyjnego (NSA) w Warszawie z 29 XI 2016 r., sygn. I OZ 1484/16, Legalis nr 1550520, w którym wskazano, że „[w] rozpoznawanej sprawie skarżący zarzucił Rzecznikowi Ubezpieczonych bezczynność polegającą na niedoręczeniu polisy OC. Sąd I instancji prawidłowo stwierdził, że 


\section{Dostęp Rzecznika Finansowego do akt sprawy na podstawie art. $63^{5}$ k.p.c.}

Kolejna kwestia związana jest z możliwością stosowania przez Rzecznika Finansowego art. $63^{5}$ k.p.c., do którego art. 28 ustawy o Rzeczniku nie odwołuje się wprost ${ }^{59}$. Prima facie może się zatem pojawić wątpliwość, czy art. $63^{5}$ k.p.c. - podobnie jak art. 63 k.p.c. - znajduje odpowiednie zastosowanie do Rzecznika Finansowego. Wydaje się, że art. $63^{5}$ k.p.c. w sposób naturalny koresponduje z art. 28 ustawy o Rzeczniku, który to przepis należy właśnie uznać za "odrębne przepisy", o których mowa $w$ art. $63^{5}$ k.p.c. Tym samym na wniosek Rzecznika Finansowego sąd może zezwolić, aby pogląd został przedstawiony także ustnie na rozprawie. Praktyczne znaczenie takiego uprawnienia wydaje się jednak znikome wobec tego, że zasadą jest wyrażanie poglądu w formie pisemnej. Wynika to $\mathrm{z}$ faktu, iż w zasadzie tylko taka forma pozwala na wnikliwe i precyzyjne zaprezentowanie wywodu (najczęściej prawnego), a także uzasadnienie wszystkich istotnych aspektów i okoliczności danej sprawy, w której pogląd jest wyrażany.

Odpowiednie stosowanie art. $63^{5}$ k.p.c. oznacza również prawo Rzecznika Finansowego do zwrócenia się do sądu o udostępnienie akt sprawy w zakresie niezbędnym do przedstawienia poglądu. Dyspozycja

przedmiotowa skarga na bezczynność nie należy do właściwości sądu administracyjnego, albowiem nie dotyczy żadnego z aktów administracyjnych wymienionych w art. $3 \S 2$ pkt 1-4 p.p.s.a. W tej sytuacji prawo pomocy nie przysługuje i Sąd zasadnie odmówił skarżącemu przyznania prawa pomocy na podstawie art. 247 p.p.s.a."; wyrok NSA w Warszawie z 6 VII 2004 r., sygn. OSK 547/04, Legalis nr 66298, w którym stwierdzono, że „[w] sytuacji gdy skarga na bezczynność została wniesiona w sprawie, do której załatwienia nie jest właściwy wskazany przez stronę organ, a która ponadto nie podlega załatwieniu w drodze administracyjnej, lecz w drodze umowy, właściwe jest orzeczenie przez sąd administracyjny o odrzuceniu skargi jako niedopuszczalnej (art. 27 ust. 2 Ustawy z dnia 11 V 1995 r. o Naczelnym Sądzie Administracyjnym - Dz.U. Nr 74, poz. 368 ze zm., obecnie art. 58 § 1 pkt 1 Ustawy z dnia 30 VIII 2002 r. - Prawo o postępowaniu przed sądami administracyjnymi - Dz.U. Nr 153, poz. 1270)".

${ }^{59}$ Artykuł $63^{5}$ k.p.c. wprowadzony został Ustawą z dnia 10 VI 2014 r. o zmianie ustawy o ochronie konkurencji i konsumentów oraz ustawy - Kodeks postępowania cywilnego (Dz.U. poz. 945), która weszła w życie 18 I 2015 r. Zgodnie z jego treścią: „\$ 1. Jeżeli przepisy odrębne przyznają określonym podmiotom, które nie uczestniczą w sprawie, uprawnienie do przedstawiania sądowi istotnego dla sprawy poglądu, do podmiotów tych stosuje się odpowiednio przepis art. 63. Jednak na wniosek podmiotu uprawnionego sąd może zezwolić, aby pogląd został przedstawiony także ustnie na rozprawie. § 2 . Na wniosek podmiotu uprawnionego sąd udostępnia akta sprawy w zakresie niezbędnym do przedstawienia poglądu". 
art. $63^{5} \S 2$ k.p.c. nie pozostawia wątpliwości, że przekazanie akt jest obowiązkiem sądu. W praktyce wątpliwości może budzić, jaki zakres akt sprawy należy uznać za niezbędny, a także kto - sąd czy Rzecznik uprawniony jest do określenia niezbędnego zakresu. Wydaje się przy tym, że za zbyt uproszczony należy uznać pogląd, iż o tym, w jakim zakresie akta zostaną udostępnione, decyduje sąd ${ }^{60}$.

Jeżeli wniosek o wyrażenie istotnego poglądu kierowany jest przez klienta, kluczowa powinna być jego treść. Jakkolwiek wniosek klienta nie zobowiązuje Rzecznika Finansowego do wydania istotnego poglądu, żądanie dostępu do akt sprawy co do zasady nie powinno wykraczać poza ten wniosek. Tym samym treść wniosku powinna determinować zakres żądanych przez Rzecznika akt sprawy, a także postępowanie sądu w tym zakresie. W praktyce wniosek Rzecznika Finansowego kierowany do sądu wskazywać będzie konieczność udostępnienia kopii pism procesowych znajdujących się $\mathrm{w}$ aktach sprawy, a więc pozwu, odpowiedzi na pozew, dalszych pism procesowych, jeżeli zostały przez strony wniesione, załączników do tych pism, zarzutów lub sprzeciwu od nakazu zapłaty (jeżeli w sprawie wydany został nakaz zapłaty), a także - w zależności od etapu postępowania - orzeczeń (wyroków, postanowień) i wreszcie innych dokumentów, jeżeli mogłyby się okazać istotne dla rozstrzygnięcia sprawy (opinii biegłych, protokołów itp.). Jeżeli natomiast wniosek o wyrażenie poglądu kierowany jest przez sąd, zasadniczo to w jego gestii leży, w jakim zakresie za zasadne uzna przekazanie akt sprawy ${ }^{61}$.

Należy przy tym pamiętać, że nieudostępnienie akt sprawy w zakresie, o jaki wnosi Rzecznik, może stanowić przyczynę braku wyrażenia poglądu. Brak dostępu do pełnego zakresu akt sprawy (bądź też w takim zakresie, w jakim Rzecznik uznaje to za właściwe), w konkretnych sytuacjach może uniemożliwiać rzetelną analizę całokształtu okoliczności danej sprawy, a w konsekwencji stanowić podstawę do odmowy wyrażenia istotnego poglądu.

${ }^{60}$ E. Rudkowska-Ząbczyk, Komentarz do art. $63^{5}$, w: Kodeks postepowania cywilnego. Komentarz, pod red. E. Marszałkowskiej-Krześ, Warszawa 2017.

${ }^{61} \mathrm{~W}$ tym zakresie warto jednak rozróżnić dwie sytuacje: wniosek sądu o wyrażenie poglądu przez Rzecznika Finansowego może stanowić jego własną inicjatywę albo stanowić efekt uwzględnienia wniosku strony procesu o zwrócenie się przez sąd do Rzecznika Finansowego o wydanie istotnego poglądu. 
Pogląd może być również wydany z własnej inicjatywy Rzecznika Finansowego w takim sensie, że nie będzie poprzedzony ani wnioskiem klienta, ani wnioskiem sądu. Informację o postępowaniu sądowym Rzecznik może powziąć np. z mediów. Wydaje się, że w takim przypadku wyrażenie poglądu powinno być jednak podyktowane nie tylko koniecznością ochrony interesów klienta (klientów) podmiotu rynku finansowego, ale ponadto powinny za tym przemawiać szczególne okoliczności. Zwłaszcza w takiej sytuacji, kiedy to do Rzecznika nie zwrócił się ani sąd, ani klient, wątpliwości może budzić uprawnienie Rzecznika do zwrócenia się do sądu o udostępnienie akt sprawy. Literalne brzmienie art. $63^{5} \S 2$ k.p.c. mogłoby sugerować, że wówczas Rzecznikowi takie prawo by przysługiwało, sąd zaś - w jakikolwiek sposób decydując o zakresie - miałby obowiązek ich udostępnienia. Takie podejście trudno jednak zaaprobować ze względu na oczywistą kolizję wartości. Z jednej strony pewnego interesu publicznego, który mógłby uzasadniać dostęp Rzecznika Finansowego do akt sprawy, co z kolei umożliwiłoby ich analizę i ewentualne wydanie poglądu istotnego dla sprawy. $Z$ drugiej zaś strony interesu stron i prawa do ochrony ich prywatności. Jakkolwiek wydaje się to mało prawdopodobne, żadna ze stron (nawet klient podmiotu rynku finansowego) może nie chcieć ingerencji Rzecznika Finansowego w postępowanie sądowe. Wskazówkę interpretacyjną w omawianym zakresie może stanowić art. 25 ust. 2 ustawy o Rzeczniku, który przewiduje, że wystąpienie o udzielenie informacji lub wyjaśnień w sprawach indywidualnych może nastąpić wyłącznie za zgodą klienta, którego sprawa dotyczy. Dyspozycja tego przepisu nie odnosi się bezpośrednio do uprawnienia Rzecznika Finansowego wynikającego z art. $63^{5} \S 2$ k.p.c., gdyż funkcjonalnie powiązana jest $\mathrm{z}$ treścią art. 25 ust. 1 pkt 1 ustawy o Rzeczniku, a więc z uprawnieniem Rzecznika do występowania do podmiotów rynku finansowego oraz innych podmiotów, których działalność wiąże się z rozpatrywaną sprawą, o udzielenie informacji lub wyjaśnień, udostępnienie akt oraz dokumentów. Ustawa o Rzeczniku ogranicza wspomniane prawo Rzecznika, uzależniając możliwość pozyskania wspomnianych informacji w sprawach indywidualnych od zgody klienta. Oczywistym celem takiej regulacji jest ochrona prywatności klientów. Dostęp Rzecznika Finansowego do prywatnych informacji klientów możliwy jest zatem tylko wówczas, gdy zostaną one przekazane Rzecznikowi bezpośrednio przez klienta, bądź też jeżeli wyrazi 
on zgodę na ich pozyskiwanie od podmiotu rynku finansowego lub innych podmiotów ${ }^{62}$. Uzasadnione wydaje się analogiczne kształtowanie uprawnienia Rzecznika Finansowego wynikającego z art. $63^{5} \S 2$ k.p.c.

\section{Treść, zakres i charakter prawny istotnego poglądu}

Największe wątpliwości mogą budzić: dopuszczalny zakres, treść, a także charakter prawny istotnego poglądu. W odniesieniu do tych kwestii oceny doktryny nie są jednolite, niemniej fakultatywny charakter istotnego poglądu, a także fakt, że nie wiąże on sądu, przemawiają za tym, aby mógł się on kształtować możliwie szeroko. Dla sądu stanowi on materiał opiniodawczy o charakterze pomocniczym ${ }^{63}$. Nie następuje więc ingerencja $w$ niezawisłość i niezależność sądu. Należy zatem przyjąć, że wyłącznie w gestii Rzecznika Finansowego pozostaje, jaka będzie treść istotnego poglądu, przy czym postuluje się, aby miał on charakter obiektywny ${ }^{64}$. Przyjmuje się, że może on wyrażać ocenę zarówno stanu faktycznego sprawy, jak i stanu prawnego istotnego dla rozstrzygnięcia danej sprawy ${ }^{65}$. Może więc zawierać nie tylko ocenę prawną (np. wskazywać, w jaki sposób określony przepis powinien być interpretowany lub stosowany), ale też dotyczyć okoliczności faktycznych sprawy ${ }^{66}$. Stanowisko co do faktów (i ich oceny) może mieć bowiem wpływ na wykładnię prawa i na jego zastosowanie ${ }^{67}$.

${ }^{62}$ Zgodnie z art. 25 ust. 1 in principio ustawy o Rzeczniku Rzecznik lub upoważniony przez niego pracownik Biura Rzecznika może występować o udzielenie informacji bądź wyjaśnień, udostępnienie akt oraz dokumentów nie tylko do podmiotów rynku finansowego, ale również do innych podmiotów, których działalność wiąże się z rozpatrywaną sprawą.

${ }^{63}$ M. Sychowicz, op. cit.

${ }^{64}$ Ibidem. Warto dodać, że w tych przypadkach, w których treść ewentualnego istotnego poglądu nie służyłaby ochronie praw lub interesów klienta podmiotu rynku finansowego, w praktyce może nastąpić odmowa jego wydania.

${ }^{65}$ E. Rudkowska-Ząbczyk, Komentarz do art. 63, w: Kodeks postępowania cywilnego...

${ }^{66} \mathrm{~W}$ doktrynie wskazuje się, że "[c] hodzi tu o pogląd istotny dla sprawy, który ma dotyczyć - przede wszystkim - zagadnień faktycznych. Nie jest jednak wykluczone wypowiadanie się przez organizację w kwestii wykładni przepisów prawa. Pogląd organizacji społecznej może mieć istotne znaczenie w razie stosowania klauzul generalnych (na przykład zwyczajów funkcjonujących w określonych stosunkach społecznych lub środowisku)", M. Uliasz, op. cit.

${ }^{67}$ M. Sychowicz, op. cit. Autor wskazuje również słusznie: „[n]ie można więc wyłączyć możliwości przedstawienia przez organizację pozarządową poglądu (w kwestiach faktycznych), który może mieć znaczenie dla rozstrzygnięcia kwestii prawnych. 
Istotny pogląd może mieć charakter ogólny w tym sensie, że opisuje pewne okoliczności lub zjawiska na rynku (finansowym), a w szczególności w zakresie ochrony klientów podmiotów rynku finansowego. Może się więc odwoływać do innych spraw będących przedmiotem analizy Rzecznika Finansowego, które ze względu na podobieństwo lub inne okoliczności mogą mieć znaczenie dla tej sprawy, w której jest wyrażany ${ }^{68}$. Może mieć również charakter szczegółowy, tzn. odnosić się wyłącznie do okoliczności konkretnej sprawy i w tym zakresie wyrażać ocenę stanu faktycznego lub prawnego. Nie należy też wykluczać możliwości wydania istotnego poglądu zawierającego wszystkie wyżej wskazane elementy. Taki pogląd odnosiłby się do konkretnych okoliczności faktycznych lub prawnych sprawy, a ponadto zawierałby oceny czy spostrzeżenia o charakterze bardziej ogólnym, a mogącym mieć znaczenie dla sprawy.

W tym kontekście aktualizuje się pytanie, czy istotny pogląd może zawierać nowe twierdzenia, okoliczności faktyczne lub wskazywać na potrzebę ich ustalenia przez sąd. Wiąże się to również z pytaniem, czy istotny pogląd stanowi lub może stanowić środek dowodowy. W doktrynie wskazuje się, że istotny pogląd tworzy element materiału procesowego w najszerszym tego słowa znaczeniu, ale jednocześnie nie stanowi środka dowodowego ${ }^{69}$. Co do zasady takie podejście należy uznać za słuszne. Prima facie istotny pogląd można by rozpatrywać jako dokument urzędowy w rozumieniu art. 244 k.p.c. Taka kwalifikacja nie wydaje się jednak przekonująca z kilku powodów. Po pierwsze, dokument urzędowy powinien być sporządzony w przepisanej formie, przepisy co do formy zawarte są zaś zwłaszcza w k.p.a., a także w ustawach regulujących poszczególne rodzaje działalności urzędowej ${ }^{70}$. Formę (wymogi formalne) istotnego poglądu jako pisma procesowego wyznacza natomiast k.p.c. Po drugie, istotny pogląd z założenia stanowi odrębną od środków dowodowych instytucję $\mathrm{w}$ ramach postępowania cywilnego, mającą swoją podstawę prawną w art. 63 k.p.c. Niemniej w doktrynie wskazuje się słusznie, że istotny pogląd pełni swego rodzaju funkcję „biegłego

Przedmiotem poglądu organizacji pozarządowej mogą być przede wszystkim fakty, ale także i «pewne oceny wchodzące w skład podstawy tak faktycznej, jak i prawnej orzeczenia» (S. Włodyka, Strony w procesie cywilnym, s. 27)".

${ }^{68}$ Ibidem.

${ }^{69}$ Ibidem.

${ }^{70}$ E. Rudkowska-Ząbczyk, Komentarz do art. 244 k.p.c., w: Kodeks postępowania cywilnego... 
społecznego"71 i powinien mieć na celu pomóc sądowi w wyrobieniu sobie określonego przekonania o okolicznościach faktycznych i zagadnieniach prawnych istotnych w sprawie ${ }^{72}$. Rolą Rzecznika Finansowego jest więc wsparcie sądu swoją wiedzą i doświadczeniem zwłaszcza w zakresie zagadnień związanych z rynkiem finansowym i relacjami podmiotów rynku finansowego z klientami ${ }^{73}$. Wychodząc z takich założeń, nawet słusznie przyjmując, że istotny pogląd nie stanowi środka dowodowego sensu stricto ${ }^{74}$, nie sposób nie dostrzec, iż w praktyce może realizować zbliżoną funkcję. Z tego powodu trudno się zgodzić z twierdzeniem, że istotny pogląd nie może zawierać wskazania nowych faktów lub dowodów ${ }^{75}$. Przecież to właśnie Rzecznik Finansowy jako organ wyspecjalizowany w dziedzinie szeroko rozumianego rynku finansowego może posiadać szczególną wiedzę (której nie będą mieli ani klient, ani sąd) na temat praktyk rynkowych podmiotów rynku finansowego lub innych okoliczności mogących mieć znaczenie dla rozstrzygnięcia danej sprawy. $W$ zasadzie to powinno być sednem istotnego poglądu niezależnie od tego, czy wyrażany jest przez Rzecznika Finansowego, Prezesa UOKiK czy organizację pozarządową. Pogląd powinien być zgodnie z jego określeniem - istotny dla sprawy. Wyrażona w istotnym poglądzie argumentacja powinna ukazywać sądowi i stronom postępowania nowe, szersze lub inne spojrzenie (często właśnie wynikające z doświadczeń Rzecznika Finansowego) na wyłaniający się problem. Istotność ta może się wyrażać w nowej - dotychczas niepodnoszonej przez klienta lub jego pełnomocnika - argumentacji dotyczącej np. wykładni przepisów, oceny prawnej czy oceny okoliczności faktycznych sprawy. Brak podstaw, by przyjąć, że nie może się również wyrażać

\footnotetext{
${ }^{71}$ M. Sychowicz, op. cit.

${ }^{72}$ M. Sorysz, Komentarz do art. 63, w: Kodeks postępowania cywilnego, t. 1: Komentarz. Art. 1-729, pod red. A. Góry-Błaszczykowskiej, Warszawa 2015.

${ }^{73} \mathrm{~W}$ odniesieniu do kompetencji Prezesa UOKiK do wydawania istotnych dla sprawy poglądów w uzasadnieniu do rządowego projektu ustawy o zmianie ustawy o ochronie konkurencji i konsumentów oraz niektórych innych ustaw (druk nr 3662/VII kadencja), s. 17, http://www.sejm.gov.pl/sejm7.nsf/druk.xsp?nr=3662 (dostęp: 21 II 2018), wskazano, iż "[p]rzewiduje się również nową kompetencję Prezesa UOKiK - jeżeli Prezes UOKiK stwierdzi, że przemawia za tym interes publiczny, przedstawi sądowi istotny dla sprawy pogląd w sprawach dotyczących ochrony konkurencji i konsumentów. Instrument ten ma na celu zapewnienie transferu wiedzy i doświadczeń z UOKiK do sądów powszechnych". Podobnie istotny pogląd Rzecznika Finansowego ma na celu zapewnienie transferu wiedzy i doświadczeń Rzecznika do sądów.

${ }^{74}$ E. Rudkowska-Ząbczyk, Komentarz do art. 63 k.p.c., w: Kodeks postępowania cywilnego...

${ }^{75}$ Ibidem.
} 
w postaci odesłania do nowych faktów lub dowodów. Takie działanie, jako mogące się przyczynić do wszechstronnego rozpatrzenia sprawy, realizowałoby też postulat dążenia do prawdy materialnej. Biorąc pod uwagę powyższe, brak jest racjonalnych argumentów, aby wykluczać możliwość powoływania $\mathrm{w}$ istotnym poglądzie nowych faktów lub dowodów oraz ocen Rzecznika Finansowego w tym zakresie, a także możliwości wskazania potrzeby ustalenia przez sąd określonych faktów (mogących mieć istotne znaczenie dla sprawy) z wykorzystaniem odpowiednich dowodów (nawet jeżeli Rzecznik Finansowy ich nie posiada). Artykuł 28 ustawy o Rzeczniku, a także art. 63 i $63^{5}$ k.p.c. nie dają żadnych podstaw do zawężającej interpretacji w omawianym zakresie. Oczywiście, ustalenie tych faktów i przeprowadzenie dowodów powinno nastąpić lege artis, a więc zgodnie z właściwymi przepisami k.p.c., na wniosek strony lub z własnej inicjatywy sądu ${ }^{76}$.

W tym kontekście istotny pogląd może nie pozostawać bez wpływu na ocenę sądu, czy określone twierdzenia lub dowody zgłaszane przez strony należy uznać za spóźnione, w związku z czym podlegałyby pominięciu. To właśnie treść istotnego poglądu może dać asumpt do zgłaszania przez strony (zwłaszcza klienta) nowych twierdzeń i dowodów, a zarazem może uprawdopodabniać, że potrzeba ich powołania wynikła dopiero po zapoznaniu się z treścią istotnego poglądu, w związku z czym ich niezgłoszenie na wcześniejszym etapie sprawy nastąpiło bez winy strony.

Uwzględniając to, że pogląd stanowi element materiału dowodowego w szerokim znaczeniu, sąd powinien ustosunkować się do niego i dać temu wyraz w uzasadnieniu orzeczenia, wskazując przyczyny uwzględnienia lub odmowy uwzględnienia okoliczności bądź ocen w nim zawartych ${ }^{77}$.

\section{Kompetencja Prezesa UOKiK do przedstawienia sądowi istotnego dla sprawy poglądu}

Omawiając przedmiotową problematykę, warto również wspomnieć o art. 31d ustawy o ochronie konkurencji i konsumentów, który obowiązuje od 17 kwietnia 2016 r. Zgodnie z tym przepisem Prezes UOKiK, jeżeli uzna, że przemawia za tym interes publiczny, przedstawia sądowi

\footnotetext{
${ }^{76}$ Artykuł 232 k.p.c.

${ }^{77}$ M. Sychowicz, op. cit.
} 
istotny dla sprawy pogląd w sprawach dotyczących ochrony konkurencji i konsumentów.

Norma ta zatem - podobnie jak art. 28 ustawy o Rzeczniku w przypadku Rzecznika Finansowego - kształtuje kompetencję Prezesa UOKiK do przedstawienia sądowi istotnego dla sprawy poglądu. Jakkolwiek instrument, jakim jest istotny pogląd, w obu przypadkach jest tożsamy, przesłanki uprawniające do jego wyrażenia są nieco odmienne. Rzecznik Finansowy w naturalny sposób ograniczony jest kompetencjami wynikającymi z ustawy o Rzeczniku, natomiast uprawnienie Prezesa UOKiK jest szersze, gdyż może on przedstawić pogląd we wszystkich sprawach dotyczących ochrony konkurencji i konsumentów, bez względu na sektor lub branżę. Z drugiej strony, uprawnienie Prezesa UOKiK formalnie ograniczane jest przesłanką interesu publicznego. Jednak o tym, czy za przedstawieniem w sprawie istotnego poglądu przemawia interes publiczny, czy też nie, decyduje wyłącznie Prezes UOKiK i kwestia ta nie powinna podlegać weryfikacji przez sąd. Stanowisko takie uzasadnione jest niewiążącym charakterem istotnego poglądu. Sąd nie ma więc obowiązku uwzględnić, czy też podzielić ocen lub twierdzeń zawartych w istotnym poglądzie, ale jednocześnie nie powinien uniemożliwiać Prezesowi UOKiK jego przedstawienia. Kompetencja Rzecznika Finansowego nie jest natomiast ograniczona przesłanką interesu publicznego. Rzecznik Finansowy może zatem wyrazić istotny pogląd nawet wówczas, gdyby nie przemawiał za tym interes publiczny, pod warunkiem że będzie to miało na celu ochronę praw lub interesów klienta podmiotu rynku finansowego. Takie rozwiązanie z pewnością należy ocenić pozytywnie - wszak kluczowym zadaniem Rzecznika Finansowego jest ochrona klientów podmiotów rynku finansowego i reprezentowanie ich interesów w indywidualnych sprawach ${ }^{78}$. Dodać należy, że podstawowym celem instytucji istotnego poglądu jest wsparcie strony postępowania $\mathrm{w}$ jej indywidualnej sprawie. $Z$ założenia nie jest to więc narzędzie służące ochronie zbiorowych interesów klientów podmiotów rynku finansowego. Mimo to w praktyce może się zdarzyć, że istotny pogląd stanowić będzie wsparcie dla większej grupy klientów, $\mathrm{np}$. $\mathrm{w}$ przypadku przedstawienia istotnego poglądu w postępowaniu grupowym ${ }^{79}$ bądź wtedy, gdy istotne poglądy przedstawiane są w wielu sprawach, których przedmiot sporu jest tożsamy lub zbliżony.

${ }^{78}$ Artykuł 17 ust. 1 pkt 1 i 2 ustawy o Rzeczniku.

${ }^{79}$ Ustawa z dnia 17 XII 2009 r. o dochodzeniu roszczeń w postępowaniu grupowym (Dz.U. 2010 Nr 7, poz. 44 ze zm.). 


\section{Istotny pogląd a dostęp do informacji publicznej}

Na marginesie powyższych rozważań warto wskazać, że w praktyce mogą się pojawić wątpliwości, czy treść istotnego poglądu może stanowić informację publiczną $w$ rozumieniu przepisów u.o.d.i.p. Problematyka ta wykracza poza ramy niniejszego opracowania i wymagałaby pogłębionej analizy, niemniej zasadne jest zasygnalizowanie istoty problemu. Nie wchodząc zatem w szczegółowe rozważania, warto poczynić kilka uwag o charakterze ogólnym.

W doktrynie i w orzecznictwie przyjmuje się - m.in. ze względu na treść art. 61 ust. 1 i 2 Konstytucji RP - szerokie rozumienie pojęcia „informacja publiczna" ${ }^{\prime \prime 0}$. W przypadku instrumentu, jakim jest istotny pogląd, sprawa jest jednak złożona. Jakkolwiek istotny pogląd wyrażany jest przez organ, tj. Rzecznika Finansowego, dotyczy on jednak konkretnej i indywidualnej sprawy (sporu) klienta (klientów) podmiotu rynku finansowego z tymże podmiotem, a więc sprawy, która zasadniczo nie ma charakteru publicznoprawnego. W judykaturze wskazuje się zaś, że sprawami publicznymi nie są konkretne, indywidualne sprawy danej osoby, zwłaszcza o charakterze prywatnym ${ }^{81}$. Jednakowoż w orzecznictwie sądów administracyjnych ugruntowany wydaje się pogląd, że orzeczenia sądowe, a więc zarówno wyroki, jak i postanowienia - jako wydane w sprawie przez sąd w ramach jego działalności orzeczniczej opartej na przepisach powszechnie obowiązującego prawa - są danymi publicznymi i podlegają udostępnieniu po ich zanonimizowaniu ${ }^{82}$. Istotny pogląd nie stanowi jednak orzeczenia, nie rozstrzyga bowiem sprawy ani w postępowaniu administracyjnym, ani w postępowaniu cywilnym. $Z$ punktu widzenia procedury cywilnej jest dosyć specyficznym instrumentem, z którego Rzecznik Finansowy może korzystać na podstawie art. 28 ustawy o Rzeczniku w zw. z art. 63 k.p.c., a więc nie na podstawie przepisów k.p.a. Ma on dla sądu wyłącznie opiniodawczy i pomocniczy charakter. Nie stanowi jednak rozstrzygnięcia ani w rozumieniu przepisów k.p.a. (decyzja lub postanowienie), ani w rozumieniu przepisów k.p.c. czy p.p.s.a. (wyrok, postanowienie, zarządzenie). Wydaje się, że nie stanowi również dokumentu urzędowego. Istotny pogląd nie ma więc charakteru

${ }^{80}$ Zob. wyrok NSA z 25 VIII 2016 r., sygn. I OSK 182/15, Legalis nr 1588836, i przywołane tam orzecznictwo.

${ }^{81}$ Wyrok NSA z 7 III 2012 r., sygn. I OSK 2265/11, Legalis nr 551941.

${ }^{82}$ Zob.: wyrok NSA z 25 VIII 2016 r., sygn. I OSK 182/15, Legalis nr 1588836, i przywołane tam orzecznictwo; wyrok NSA z 11 VIII 2011 r., sygn. I OSK 933/11, Legalis nr 486801. 
wiążącego dla sądu, stron postępowania cywilnego, organów ani innych podmiotów, a zatem w odróżnieniu od orzeczenia sądowego lub decyzji administracyjnej, nie kształtuje niczyich praw bądź obowiązków ${ }^{83}$.

Ponadto należy pamiętać, że u.o.d.i.p. przewiduje - z pewnymi wyjątkami ${ }^{84}$ - ograniczenia prawa do informacji publicznej ${ }^{85}, \mathrm{np} . \mathrm{w}$ zakresie i na zasadach określonych w przepisach o ochronie informacji niejawnych oraz o ochronie innych tajemnic ustawowo chronionych ${ }^{86}$, a także ze względu na prywatność osoby fizycznej lub tajemnicę przedsiębiorcy ${ }^{87}$. Istotne poglądy co do zasady zawierać będą dane osobowe, a także prywatne informacje klientów, niekiedy zaś mogą się odwoływać do informacji stanowiących tajemnicę przedsiębiorstwa ${ }^{88}$.

W świetle powyższego wydaje się, że co do zasady treść wyrażanego przez Rzecznika Finansowego istotnego poglądu, a także dokumenty czy akta, na podstawie których został wydany, nie będą miały charakteru informacji publicznej ${ }^{89}$. Jednocześnie nie sposób wykluczyć, że w konkretnych okolicznościach - w szczególności biorąc pod uwagę treść art. 5 ust. 2 zd. 2, ust. 3 lub ust. 4 u.o.d.i.p. - istotny pogląd będzie mógł zawierać informacje mające taki charakter.

W tym kontekście warto jednak dodać, że nawet przy założeniu, iż w konkretnych okolicznościach istotny pogląd wyrażony przez Rzecznika Finansowego stanowi - choćby w pewnym zakresie - informację

${ }^{83}$ Oczywiste jest też, że w odniesieniu do istotnego poglądu brak jest odpowiednika art. $365 \S 1$ k.p.c. lub art. 170 p.p.s.a., zgodnie z którymi prawomocne orzeczenie sądu wiąże nie tylko strony i sąd, który je wydał, lecz również inne sądy oraz inne organy państwowe i organy administracji publicznej, a w przypadkach w ustawie przewidzianych także inne osoby.

${ }^{84}$ Artykuł 5 ust. 2 zd. 2, ust. 3 i ust. 4 u.o.d.i.p.

${ }^{85}$ Artykuł 5 u.o.d.i.p.

${ }^{86}$ Artykuł 5 ust. 1 u.o.d.i.p.

${ }^{87}$ Artykuł 5 ust. 2 zd. 1 u.o.d.i.p.

${ }^{88}$ Zgodnie z art. 11 ust. 4 Ustawy z dnia 16 IV 1993 r. o zwalczaniu nieuczciwej konkurencji (Dz.U. Nr 47, poz. 211 ze zm.) „[p]rzez tajemnicę przedsiębiorstwa rozumie się nieujawnione do wiadomości publicznej informacje techniczne, technologiczne, handlowe, organizacyjne przedsiębiorstwa lub inne informacje posiadające wartość gospodarczą, co do których przedsiębiorca podjął niezbędne działania w celu zachowania ich poufności".

${ }^{89}$ Przyjęcie, że w konkretnej sprawie wnioskowana informacja nie ma charakteru informacji publicznej, nie wymaga wydania decyzji administracyjnej w tym zakresie, wystarczy zawiadomienie wnoszącego, że żądane dane nie mieszczą się w pojęciu informacji publicznej. Zob.: wyrok NSA z 17 XII 2003 r., sygn. II SA/Gd 1153/03, LEX nr 299295; wyrok NSA z 25 III 2003 r., sygn. II SA 4059/02, Legalis nr 94936; postanowienie NSA z 18 III 2010 r., sygn. I OSK 405/10, Legalis nr 755825. 
publiczna, to zgodnie $z$ art. 3 ust. 1 pkt 1 u.o.d.i.p. prawo do informacji publicznej obejmuje uprawnienie do uzyskania informacji publicznej, w którym mieści się również prawo do uzyskania informacji przetworzonej, jednak tylko w takim zakresie, $\mathrm{w}$ jakim jest to szczególnie istotne dla interesu publicznego. W praktyce treść udostępnianego istotnego poglądu nie będzie miała charakteru informacji prostej, lecz stanowić będzie informację przetworzoną ${ }^{90}$. Zasadnicza treść istotnego poglądu będzie musiała bowiem ulec zmianie przed jego udostępnieniem ze względu na konieczność usunięcia informacji chronionych prawem - w zasadzie zawsze wymagać więc będzie uprzedniego zanonimizowania ${ }^{91}$. Tym samym ujawnienie tego rodzaju informacji możliwe byłoby tylko w takim zakresie, w jakim wnioskodawca wykaże, że jest to szczególnie istotne dla interesu publicznego.

Informację publiczną może natomiast stanowić informacja o stanie i liczbie przyjmowanych wniosków o wyrażenie istotnego poglądu, kolejności ich rozpatrywania oraz prowadzonych rejestrach, ewidencjach i archiwach z tym związanych, a w szczególności o liczbie wyrażonych przez Rzecznika Finansowego poglądów bądź zagadnieniach, jakich poglądy dotyczą.

\section{Podsumowanie}

Uprawnienie Rzecznika Finansowego do wydania istotnego poglądu ma na celu wspieranie klientów podmiotów rynku finansowego w sporach z tymi podmiotami. Przedłożenie istotnego poglądu ma umożliwić

${ }^{90}$ W wyroku z 21 IX 2012 r., sygn. I OSK 1477/12, Legalis nr 552344, NSA wskazał, iż „[z]arówno w doktrynie, jak też orzecznictwie sądów administracyjnych utrwalił się pogląd, że informacją prostą jest informacja, której zasadnicza treść nie ulega zmianie przed jej udostępnieniem. Natomiast informacja przetworzona jest jakościowo nową informacją nieistniejącą dotychczas w przyjętej ostatecznie treści i postaci, chociaż jej źródłem są materiały znajdujące się w posiadaniu zobowiązanego. [...] Ze względu jednak na treść żądania, udostępnienie wnioskodawcy konkretnej informacji publicznej nawet o wspomnianym wyżej prostym charakterze, wiązać się może z potrzebą przeprowadzenia odpowiednich analiz, zestawień, wyciągów, usuwania danych chronionych prawem. Takie zabiegi czynią zatem takie informacje proste, informacją przetworzona, której udzielenie jest skorelowane z potrzebą istnienia przesłanki interesu".

${ }^{91}$ Anonimizacja polega na kompleksowym przeanalizowaniu treści wnioskowanej informacji w celu usunięcia wszelkich danych chronionych prawem (np. informacji prywatnych, danych osobowych lub informacji objętych tajemnica przedsiębiorstwa) i de facto wymaga przygotowania odrębnego dokumentu. 
transfer wiedzy i doświadczeń Rzecznika Finansowego - jako organu wyspecjalizowanego w sprawach dotyczących szeroko rozumianego rynku finansowego - do sądu. Z tego powodu treść i zakres istotnego poglądu powinny się kształtować możliwie szeroko i - podobnie jak decyzja o tym, czy w ogóle wydać istotny pogląd w sprawie - pozostawać w wyłącznej gestii Rzecznika Finansowego. Oznacza to, że z jednej strony sąd nie może zobowiązać Rzecznika Finansowego do wydania istotnego poglądu (może o to jedynie wnioskować), z drugiej zaś, że istotny pogląd może zostać wydany z własnej inicjatywy Rzecznika Finansowego, a więc bez wniosku sądu lub klienta, a także bez zgody sądu. Takie stanowisko wydaje się uzasadnione, gdyż istotny pogląd nie ma dla sądu wiążącego charakteru. Stanowi materiał opiniodawczy o charakterze pomocniczym. Należy go więc traktować jako element materiału dowodowego w szerokim znaczeniu, jednak nie będzie stanowił środka dowodowego sensu stricto. Niemniej ratio legis omawianego instrumentu, jego fakultatywny i niewiążący dla sądu charakter przemawiają za przyjęciem, że może on wskazywać nowe fakty, twierdzenia lub dowody, jeżeli w ocenie Rzecznika Finansowego mogą one mieć znaczenie dla rozstrzygnięcia sprawy. Oczywiście, ustalenie faktów i przeprowadzenie odpowiednich dowodów powinno nastąpić zgodnie z właściwymi przepisami k.p.c. Niezależnie od treści i zakresu istotnego poglądu sąd powinien się do niego ustosunkować w uzasadnieniu wyroku, stosownie do art. $328 \S 2$ k.p.c. De lege ferenda warto natomiast rozważyć doprecyzowanie przepisów ustawy o Rzeczniku, tak aby ograniczyć mogące się pojawić na tle niektórych spraw wątpliwości interpretacyjne co do tego, czy Rzecznikowi Finansowemu przysługuje kompetencja do przedstawienia sądowi istotnego poglądu.

\section{THE FINANCIAL OMBUDSMAN'S COMPETENCE TO SUBMIT OBSERVATIONS TO THE COURT AS AN INSTRUMENT AIMING TO PROTECT CLIENTS OF FINANCIAL MARKET ENTITIES}

\section{Su m mary}

The article describes the competence of the Financial Ombudsman to submit to the court of law a view (observation) relevant to a case before the court. For long this instrument has been reserved for non-governmental organisations only. In December 2007, the Insurance Ombudsman was vested with such a competence as well. However, the scope of cases in which the Insurance Ombudsman can submit observations is limited to disputes arising from insurance contracts and disputes 
concerning members of pension funds or participants of occupational pension schemes. With the establishment in October 2015 of the Financial Ombudsman (who is the legal successor of the Insurance Ombudsman), this competence has been extended to cases and disputes regarding all clients of financial market entities. Submitting an observation is intended to enable the transfer of knowledge and experience of the Financial Ombudsman as a specialist in matters concerning financial market services, to the courts of law. In practice however, certain doubts arise in regard to how this instrument should be used properly. In particular, it is not always clear in which cases the Financial Ombudsman may be allowed to submit an observation and in what circumstances such a possibility should be considered as unacceptable or undesirable. Also, the legal character of an observation and its legal nature in regard to the civil procedure is being assessed differently. Thus the question arises on what the content and scope of an observation should be based. In regard to the main task imposed on the Financial Ombudsman, namely the protection of the rights and interests of clients of financial market entities, it seems only reasonable that the content and scope of an observation as well as the decision on whether it will be submitted to the court at all remains in the exclusive judgment of the Financial Ombudsman. The main aim of the article is to analyse these issues based on the experience of the Financial Ombudsman resulting from the use of the instrument in practice.

Keywords: observations - client - financial market entity - Financial Ombudsman 